\title{
FG-30 I 9, a Human Monoclonal Antibody Recognizing Connective Tissue Growth Factor, is Subject to Target-Mediated Drug Disposition
}

\author{
Mitchell C. Brenner ' - Wojciech Krzyzanski² • James Z. Chou' • Pierre E. Signore ' Cyra K. Fung ' • \\ David Guzman' • Dongxia Li' • Weihua Zhang' • David R. Olsen ' • Viet-Tam L. Nguyen' • \\ Carolyn W. Koo' • Mark D. Sternlicht ' Kenneth E. Lipson'
}

Received: 25 January 2016 / Accepted: 30 March 2016 / Published online: 8 April 2016

(C) The Author(s) 2016. This article is published with open access at SpringerLink.com

\begin{abstract}
Purpose To evaluate and model the pharmacokinetic and pharmacodynamic behavior in rats of FG-3019, a human monoclonal antibody targeting connective tissue growth factor (CTGF).

Methods FG-3019, human CTGF (rhCTGF), or the Nterminal domain of rhCTGF were administered intravenously to rats and concentrations of these proteins as well as endogenous CTGF were determined by immunoassays. FG-3019, or ${ }^{125}$ I-labeled FG-3019, and human CTGF (rhCTGF) were co-administered to assess the impact of CTGF on the elimination rate and tissue localization of FG-3019, which was further characterized by immunohistochemical analysis. A PK/PD model for target-mediated elimination of FG-3019 was developed to fit the kinetic data.
\end{abstract}

Results FG-3019 exhibited non-linear pharmacokinetics in rats. Circulating concentrations of the $\mathrm{N}$-terminal half of CTGF increased after dosing with FG-3019, reached maximal levels after 1-5 days, and returned toward baseline levels as FG3019 cleared from the circulation, whereas the concentration of intact CTGF was unaffected by administration of FG-3019. Coadministration of rhCTGF dramatically enhanced the rate of FG-3019 elimination, redistributing the majority of ${ }^{125}$ I-labeled FG-3019 from the blood to the liver, kidney, spleen and adrenal gland. FG-3019 co-administered with CTGF was found along the sinusoids of the liver and adrenal glands, the capillaries of the

Electronic supplementary material The online version of this article (doi: | 0. | 007/s | |095-0 |6-19 |8-0) contains supplementary material, which is available to authorized users.

Mitchell C. Brenner

mbrenner@fibrogen.com

FibroGen, Inc., 409 Illinois St., San Francisco, California 94I58, USA

2 Department of Pharmaceutical Sciences, State University of New York at Buffalo, 370 Kapoor Hall, Buffalo, New York 14214, USA kidney glomeruli and in the spleen. A pharmacokinetic model for target-mediated elimination of FG-3019 was used to fit the time courses of FG-3019 and endogenous CTGF plasma concentrations, as well as time courses of rhCTGF and rhCTGF Nfragment after intravenous administration of these species.

Conclusions FG-3019 is subject to target mediated elimination in rats.

KEY WORDS Connective Tissue Growth Factor · CTGF . FG-3019 ? TMDD

$\begin{array}{ll}\text { ABBREVIATIONS } \\ \text { CTGF } & \text { Connective Tissue Growth Factor } \\ \text { CTGF-C } & \text { C-terminal half of CTGF } \\ \text { CTGF-N } & \text { N-terminal half of CTGF } \\ \text { CTGF-whole } & \text { Intact CTGF } \\ \text { Ig } & \text { Immunoglobulin } \\ \text { IV } & \text { Intravenous } \\ \text { K }_{d} & \text { Dissociation constant } \\ \text { LLOQ } & \text { Lower limit of quantitation } \\ \text { PK } & \text { Pharmacokinetics } \\ \text { RAP } & \text { Receptor associated protein } \\ \text { rhCTGF } & \text { Recombinant human CTGF } \\ \text { SD } & \text { Sprague-Dawley } \\ \text { SDS-PAGE } & \text { Sodium dodecyl sulfate } \\ & \text { polyacrylamide gel electrophoresis }\end{array}$

\section{INTRODUCTION}

Connective tissue growth factor (CTGF, CGN2) is a member of a small family of secreted monomeric proteins that are characterized by their highly conserved disulfide bonding pattern and organization into 3-4 domains having homology to other proteins (1). The four domains of CTGF are homologous to 1) IGF- 
1 binding proteins, 2) the von Willebrand factor type $\mathrm{C}$ repeat, 3) the thrombospondin type 1 repeat, and 4) a cysteine knot motif common to proteins that bind heparan sulfate proteoglycans (HSPGs), respectively. A protease susceptible linker (hinge region) interconnects domains 2 and 3, which upon cleavage produces CTGF-N (domains 1-2) and CTGF-C (domains 34). CTGF-N appears to be proteolytically stable, as it is the portion of CTGF that is commonly observed in biological fluids like plasma or urine, whereas CTGF or CTGF-C is usually not observed in biological fluids at appreciable concentrations (2).

Increased concentrations of CTGF have been reported in various chronic diseases including liver fibrosis, systemic sclerosis, diabetic nephropathy, as well as pancreatic cancer (3). Because of the association between elevated CTGF concentrations and progression of tissue remodeling diseases, inhibition of CTGF has been suggested as a therapeutic target (4). FG-3019 is a human anti-CTGF IgG1 monoclonal antibody currently under clinical investigation as a potential therapeutic for treatment of idiopathic pulmonary fibrosis, liver fibrosis and pancreatic cancer (5). FG-3019 was selected for clinical development from a panel of anti-CTGF antibodies based on its ability to recognize both human and rodent CTGF and its activity in functional assays (6). As part of the selection process, FG-3019 and several other anti-CTGF antibodies were evaluated for pharmacokinetic performance in rats. Antibodies specific to human CTGF exhibited slower clearance and longer halflives in rats than antibodies that recognized rat as well as human CTGF (unpublished observations), suggesting the potential for target-mediated antibody elimination. Here we report the assessment of FG-3019 PK in rats following IV administration, which is characterized by relatively rapid dose-dependent clearance and dose-dependent terminal half-life. We present additional experiments to understand the observed non-linear kinetics in terms of a target-mediated clearance mechanism. These experiments include an assessment of the effect of exogenous CTGF on the elimination kinetics of FG-3019 in rats, the tissue distribution of radioiodinated FG-3019 in the absence and presence of exogenous CTGF, immunohistochemical localization of unlabeled FG-3019 in rat tissues, as well as kinetic modeling of target-mediated antibody elimination. Together these studies show that complexes formed between FG-3019 and CTGF in vivo are subject to extremely rapid elimination, which dominates the pharmacokinetics at low doses, but is a minor contributor to antibody elimination at high doses.

\section{MATERIALS AND METHODS}

\section{FG-3019}

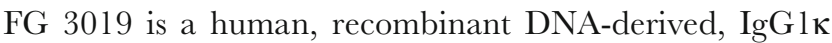
monoclonal antibody that binds to CTGF in domain 2, with high affinity $\left(\mathrm{K}_{\mathrm{d}}=0.1-0.2 \mathrm{nM}\right)$.

\section{Production of CTGF}

Recombinant human and rat CTGF (CTGF-whole or CTGF-W) and CTGF-N were expressed in CHO cells as secreted proteins. The proteins were purified from concentrated conditioned media using an antibody affinity-based purification with FG-3019-Sepharose resin followed by ion exchange chromatography with SP-Sepharose Fast Flow resin (GE Healthcare).

\section{CTGF Antibodies}

Human IgG1 monoclonal antibodies expressed in CHO cells that target the N- and C-half portions of CTGF, respectively, were used to assay for CTGF forms having an intact hinge region connecting the two halves of CTGF. The N-halfreactive antibody binds to Domain 1 of CTGF and is referred to as $\mathrm{mAb}-\mathrm{D} 1$. The $\mathrm{C}$-half reactive antibody binds to Domain 3 of CTGF and is referred to as mAb-D3. We employed a bivalent Fab "mini" antibody targeting the N-half of CTGF (referred to as "minibody") that contains a dHLX dimerization domain followed by a Myc-His peptide tag at the Cterminus of the antibody heavy chain. The minibody was expressed in E.coli and purified by immobilized metal ion chromatography (custom prepared for FibroGen by AbD Serotec (Puchheim, Germany)).

\section{Production of Receptor Associated Protein (RAP)}

Receptor associated protein (Cat. No. IRAP-514) was prepared by Innovative Research, Inc. (Novi, MI). The protein was expressed as a glutathione-S-transferase fusion protein in E.coli and purified by glutathione-agarose chromatography. The fusion protein was cleaved with thrombin and GSTcontaining species were removed by glutathione-agarose chromatography. RAP was further purified by heparin sepharose affinity chromatography (7). The purified protein $\left(0.81 \mathrm{mg} / \mathrm{ml}\right.$ based on $\left.\epsilon_{280}=0.93\right)$ was dialyzed against $20 \mathrm{mM}$ ammonium bicarbonate and then lyophilized. The final purified material was judged greater than 95\% pure by SDS-PAGE. The N-terminus of the final product has sequence GSYSREKN, which differs from the native $\mathrm{N}$ terminus of YSREKN due to the remnant sequence (Gly Ser) from the thrombin cleavage consensus sequence.

\section{Pharmacokinetics of FG-3019 in Rats}

Male Sprague-Dawley rats (purchased pre-cannulated from Charles River Labs, Hollister, CA) weighing an average of $336 \mathrm{~g}$ were housed, two per cage, with free access to food and water throughout the study. FG-3019 formulated at $0.01,0.1,1,3$ and $10 \mathrm{mg} / \mathrm{ml}$ was sterile filtered and administered ( $3 \mathrm{ml} / \mathrm{kg}$ or $10 \mathrm{ml} / \mathrm{kg}$ for the highest FG-3019 dose) to 
anesthetized rats through tail vein injection at $0.03,0.3,3,10$, 30 and $100 \mathrm{mg} / \mathrm{kg}$. Blood samples $(0.25 \mathrm{ml})$ were collected at one pre-dose and 12 post-dose time points into lithium heparin coated tubes from a catheter implanted in the jugular vein. Plasma was isolated by centrifugation and stored at $-80^{\circ} \mathrm{C}$. Results from multiple experiments were combined for pharmacokinetic analysis.

\section{Pharmacokinetics of Recombinant Human CTGF in Rats}

Procedures were similar to those for assessment of the pharmacokinetics of FG-3019. Recombinant human CTGF $(0.253$ and $0.523 \mathrm{mg} / \mathrm{ml})$ and CTGF-N (0.127 and $0.267 \mathrm{mg} / \mathrm{ml}$ ) were sterile filtered in $50 \mathrm{mM}$ Tris $-\mathrm{HCl}$, $800 \mathrm{mM}$ sodium chloride, $\mathrm{pH} 7.5$, and administered (3 ml/ $\mathrm{kg}$ ) to obtain four groups of animals (3 rats/group) dosed at 0.76 and $1.6 \mathrm{mg} / \mathrm{kg}$ with CTGF and 0.38 and $0.80 \mathrm{mg} / \mathrm{kg}$ with CTGF-N (20 and $40 \mathrm{nmol} / \mathrm{kg}$ of each form of CTGF). Blood sample collection procedures were the same as for FG3019 .

\section{Measurement of FG-3019 in Rat Plasma}

FG-3019 was measured by capturing with an E.coli produced CTGF Exon-3 peptide and detecting with a goat anti-human kappa antibody conjugated with horseradish peroxidase (Cat. No. 2060-05, Southern Biotech, AL). All samples underwent a minimum dilution of 10-fold in buffer, with further dilutions made in $10 \%$ pooled lithium heparin rat plasma. Calibrators were prepared by spiking recombinant FG-3019 into 10\% pooled rat plasma.

In samples containing high concentrations of recombinant human CTGF and in samples from low-dose $(0.03-3 \mathrm{mg} / \mathrm{kg}$ FG-3019) PK experiments, FG-3019 was measured using either a human IgG assay kit purchased from Cygnus Technologies (Cat. No. F160), or by a similar assay in which FG-3019 was captured with an anti-human IgG (Fc specific) antibody (Cat. No.12136, Sigma) and detected using a goat anti-human kappa antibody conjugated with horseradish peroxidase (Cat. No. 2060-05, Southern Biotech, AL). All samples underwent a minimum dilution of 5-fold in buffer, with further dilutions made in sample diluent provided by the vendor (for samples measured using the Cygnus Technologies assay kit) or in $20 \%$ pooled lithium heparin rat plasma. Calibrators were prepared following the vendor's instructions (Cygnus Technologies assay kit) or by spiking recombinant FG-3019 into 20\% pooled rat plasma.

Final values for each sample were determined based on the average of results for multiple dilutions having values within $20 \%$ of each other. These assays were confirmed not to be subject to interference by human CTGF.

\section{Assays for Rat CTGF}

CTGF was measured in rat plasma using one of two immunoassays (see Figure S1). One assay employed capture with mAb-D3 and detection with a Domain 2 reactive minibody conjugated with alkaline phosphatase. This assay detects forms of CTGF that have an intact hinge region connecting Domains 2 and 3, and is referred to as a W-CTGF assay. Calibrators were prepared by spiking recombinant rat CTGF into pooled rat plasma. The second assay employed capture with the Domain 2 reactive minibody followed by detection with FG-3019 and a goat anti-human kappa antibody conjugated with horseradish peroxidase (Cat. No. 206005, Southern Biotech, AL). Calibrators were prepared by spiking recombinant rat CTGF-N into pooled rat plasma. This assay (the N+W-CTGF assay) detects forms of CTGF containing Domain 2, which includes the N-terminal half of GTGF and full length CTGF. Neither of the two GTGF assays is subject to interference by FG-3019.

\section{Assay for rhCTGF in Rat Plasma}

Plasma from rats dosed with recombinant human CTGF were assayed for CTGF using two ELISAs specific to human CTGF (see Figure S1). To measure CTGF, standards, samples and quality control samples were added to 96-well plates coated with $5 \mu \mathrm{g} / \mathrm{ml}$ mAb-D3. After washing the plates, human CTGF was detected by incubation for $1.5 \mathrm{~h}$ with $500 \mathrm{ng} / \mathrm{ml}$ alkaline phosphatase-labeled mAb-D1 followed by color formation generated after addition of $\mathrm{pNPP}$ reagent. mAb-Dl does not bind to rodent forms of CTGF, making this W-CTGF assay selective for human CTGF. A second CTGF assay (human N+W-CTGF) employed microtiter plates coated with the minibody which binds to Domain 2 of human (and rat) CTGF. Human CTGF was then detected using the human specific alkaline phosphatase-labeled mAb-D1. This N+ W-CTGF assay detects both intact rhCTGF and the Nterminal fragment of rhCTGF. Calibrator data for each of the ELISA methods described above were fit to 4-parameter logistic equations.

\section{FG-30 I 9 Pharmacokinetics in Rats Following Injection of CTGF or CTGF-N}

Six rats per group were injected through the tail vein with $\mathrm{FG}$ 3019 (3 mg/kg, dose volume $3 \mathrm{ml} / \mathrm{kg}$ ). Approximately $10 \mathrm{~min}$ after dosing with FG-3019 (Figure S2), animals were dosed with buffer, or equimolar amounts of CTGF or CTGF-N $(3 \mathrm{ml} / \mathrm{kg})$. Blood samples $(0.2 \mathrm{ml})$ were collected pre-study, $5 \mathrm{~min}$ before injection of CTGF, and then $5 \mathrm{~min}, 15 \mathrm{~min}$, 0.5 h, 1 h, 3 h, 7 h, 24 h, 48 h, 3, 5, and 8 days after injection of CTGF. Each group was divided into two sub-groups of three animals, with blood sampling conducted at alternating 
time points so that no animals had more than four blood samplings over a 24 -h period. A $0.25 \mathrm{ml}$ priming blood sample was collected prior to the $0.20 \mathrm{ml}$ blood samples. The $0.25 \mathrm{ml}$ priming sample was re-injected into the animal together with $0.2 \mathrm{ml}$ of $10 \mathrm{U} / \mathrm{ml}$ heparinized saline after each blood sample collection. Blood was centrifuged at $3510 \times g$ for $10 \mathrm{~min}$ and the plasma collected and stored at $-80^{\circ} \mathrm{C}$.

\section{FG-30 I 9 Pharmacokinetics in Rats Co-Dosed with Different Amounts of CTGF}

Three rats per group were injected through the tail vein with FG-3019 (3 $\mathrm{mg} / \mathrm{kg}$, dose volume $3 \mathrm{ml} / \mathrm{kg}$ ). Approximately $10 \mathrm{~min}$ after dosing with FG-3019 (Figure S3), rats were injected through the tail vein with bolus doses of CTGF (or buffer), at molar ratios of CTGF:FG-3019 equal to $0: 1,0.5: 1,1: 1$ and 2:1 (3 ml/ $\mathrm{kg})$. Blood samples $(0.20 \mathrm{ml})$ were collected into lithium heparin coated tubes pre-study, $5 \mathrm{~min}$ before the dose of CTGF, and at $3 \mathrm{~min}, 6 \mathrm{~min}, 0.5,6,24,48$ and $144 \mathrm{~h}$ after the dose of CTGF. Blood samples $(0.2 \mathrm{ml})$ were collected and processed as described above.

\section{FG-30 I9 Pharmacokinetics in Rats Co-administered with RAP and CTGF}

Rats were cannulated through the right jugular (for blood collection) and left femoral veins (for dose administration) and allowed to recover at least 48-h after surgery before initiation of dosing. FG-3019 was administered to conscious animals ( $n=3$ or 4 per group; $1.5 \mathrm{ml} / \mathrm{kg}$ ) (Figure S4), followed 10 min later by RAP (or vehicle; $0.9 \mathrm{ml}$ ), which was followed immediately by CTGF (or vehicle; $1.5 \mathrm{ml} / \mathrm{kg}$ ). Catheters were flushed with $0.15 \mathrm{ml}$ of sterile saline after each administration of each test article. Blood samples $(0.2 \mathrm{ml})$ were collected and processed as described above.

\section{Preparation of [ $\left.{ }^{125} 1\right]-F G-3019$}

$\left[{ }^{125} \mathrm{I}\right]-\mathrm{FG}-3019(\sim 2 \mathrm{mCi} / \mathrm{mg})$ was prepared by Vitrax Radiochemicals (Placentia, CA) by chemical radioiodination of $\mathrm{FG}-3019$. The radioiodinated antibody was checked for its ability to bind CTGF by comparison with non-radioiodinated FG-3019 in a direct ELISA based on solid phase capture by CTGF Exon-3 peptide, which corresponds to Domain 2 of CTGF. The radioiodinated and non-iodinated antibodies yielded comparable dilutional behavior in the ELISA. The $\left[{ }^{125} \mathrm{I}\right]-\mathrm{FG}-3019$ was diluted to $2 \mathrm{mCi} / \mathrm{mg}$ with nonradioiodinated $\mathrm{FG}-3019$ in $0.9 \%$ saline prior to injection.

\section{Tissue Distribution and Excretion Analysis of $\left[{ }^{125} I\right]$ -FG-3019 in Rats}

The following procedures were conducted at QPS, LLC (Newark, DE). Five rats were placed on study and were given water containing $\mathrm{NaI}(10 \mathrm{mg} / \mathrm{ml})$ beginning at least $48 \mathrm{~h}$ before test article dosing and during the study. Body weights of each animal were determined prior to and on the day of dosing. The radioactive concentration and homogeneity of the dose formulation was determined before and after dosing using gamma counting analysis. Each animal received a single tail vein injection of the formulation, which contained $\left[{ }^{125} \mathrm{I}\right]$ FG-3019 in a vehicle of $0.9 \%$ saline to achieve the target dose of $10 \mathrm{mg} / \mathrm{kg}$ and a radioactivity dose of $20 \mu \mathrm{Ci} / \mathrm{kg}$ at a dose volume of $5 \mathrm{ml} / \mathrm{kg}$. One animal each was assigned to be euthanized at $0.25,2,6$, and $24 \mathrm{~h}$ post-dose. One additional animal, which was given an IV dose of $5 \mathrm{mg} / \mathrm{kg}$ of $\mathrm{rhCTGF}$ approximately $10 \mathrm{~min}$ after the administration of $\left[{ }^{125} \mathrm{I}\right]-\mathrm{FG}$ 3019 , was euthanized at $0.25 \mathrm{~h}$ after the dose of $\left[{ }^{125} \mathrm{I}\right]-\mathrm{FG}$ 3019 (5 min after administration of rhCTGF). At the scheduled times, animals were deeply anesthetized via isoflurane inhalation, a blood sample was obtained via cardiac puncture, and the animals were euthanized by freezing in a hexane dryice bath for quantitative whole body autoradiographic (QWBA) analysis. The animals were not perfused prior to freezing. Whole blood, plasma ( $\mathrm{K}_{2}$ EDTA anticoagulant), urine, feces, cage wash and wipes as well as carcasses were collected and stored at $-70^{\circ} \mathrm{C}$.

After removing the pinna, distal limbs, hair and tail, the frozen carcasses were embedded in $2 \%(w / v)$ carboxymethylcellulose and frozen into a block prior to sectioning. Internal quality control and calibration standards (blood fortified with $\left[{ }^{125} \Gamma\right.$ sodium iodide) were placed into the frozen blocks prior to sectioning to control for section thickness and image calibration. Several sections approximately $40 \mu \mathrm{m}$ thick were taken in the sagittal plane using a cryostat microtome set to $-20^{\circ} \mathrm{C}$. Sections were dehydrated prior to exposure to phosphorimaging screens. The exposed screens were scanned using a Molecular Dynamics Typhoon 9410 Phosphor Imager and data acquired as counts per $\mathrm{mm}^{2}$. Tissue concentrations of radioactivity were determined by interpolation from a standard curve based on the calibration standards and expressed in terms of $\mu \mathrm{Ci} /$ gram, which was converted to microgram equivalents of $\left[{ }^{125} \Pi\right]-\mathrm{FG}-3019$ per gram of tissue based on the specific activity of $\left[{ }^{125} \Pi\right]-F G-3019$. A single, best representative section was used from each animal for determination of tissue concentrations of radioactivity.

\section{Immunohistochemical Localization of FG-30 I9 and CTGF}

Rats received a $3 \mathrm{mg} / \mathrm{kg}$ tail vein injection of FG-3019 followed $10 \mathrm{~min}$ later by a $1.52 \mathrm{mg} / \mathrm{kg}$ injection of rhCTGF 
(CTGF:FG-3019 molar ratio of 2:1) or buffer. Control animals were dosed with the FG-3019-vehicle followed 10 min later by buffer. Animals ( $n=2$ per group) were harvested 5 min after CTGF (or buffer) administration. The lungs were perfused with ice cold saline from the right ventricle for approximately $1 \mathrm{~min}$. The animals were then perfused from the left ventricle with ice cold saline for 3 min followed by $10 \%$ buffered formalin for $3 \mathrm{~min}$. The following tissues were harvested and stored in 10\% buffered formalin: one liver lobe, both kidneys, both adrenal glands, spleen, cardiac ventricles and lungs. The lungs were stored inflated with $10 \%$ buffered formalin. Immunohistochemistry was performed on formalinfixed, paraffin-embedded tissue sections. For antigen retrieval, specimens were boiled in TRIS/EDTA buffer $(10 \mathrm{mM}$ Tris Base, $1 \mathrm{mM}$ EDTA Solution, 0.05\% Tween 20, pH 9.0) for $20 \mathrm{~min}$. Between incubations, slides were washed three times in TBST-buffer (Teknova, Hollister, CA). A specific antihuman CTGF mouse monoclonal antibody produced at FibroGen was used for CTGF detection and a rabbit antihuman IgG (Jackson Immunoresearch Lab, West Grove, PA) was used to detect FG-3019. A tyramide signal amplification system (TSA-kit, Perkin Elmer) was used for CTGF immunostaining and EnVision + system (DAKO, Carpinteria, CA) was used for FG-3019 immunostaining according to the manufacturer's instructions. Peroxidase-diaminobenzidine was used as chromogen. Slides were cover-slipped with an aqueous mounting media (Cytoseal XYL, VWR, Visalia, CA).

\section{Non-Compartmental Pharmacokinetic Analysis}

The PK parameters were estimated by a non-compartmental pharmacokinetic analysis using Phoenix WinNonlin ${ }^{\text {TM }} 6.2$ (Pharsight, A Certara ${ }^{\mathrm{TM}}$ Company, Mountain View, CA). Nominal sampling times were used to estimate all pharmacokinetic parameters unless the deviation (scheduled vs actual) was $10 \%$ (or greater) where the actual time of sample collection was used. The $\mathrm{PK}$ parameters reported consist of $\mathrm{C}_{\max }$ (maximum plasma concentration), $\mathrm{AUC}_{\text {inf }}$ (area under the concentration time curve based on extrapolation to infinity), $\mathrm{AUC}_{\text {inf }}$ /Dose (dose normalized area under the curve), $\mathrm{Cl}$ (clearance, corresponding to the overall rate of elimination of FG-3019 from plasma), $\mathrm{V}_{\mathrm{z}}$ (volume of distribution during the terminal phase), $\mathrm{V}_{\mathrm{ss}}$ (volume of distribution during the steady-state), and $t_{1 / 2}$ (terminal half-life corresponding to the log-linear slope of the observed terminal phase of the concentration-time profile). All PK parameters values were reported to three significant figures (Table $\mathrm{S} 1$ ).

\section{Compartmental Pharmacokinetic Modeling}

A pharmacokinetic $(\mathrm{PK})$ model was designed to describe the time courses of plasma concentrations of FG-3019 (Ab) and its targets CTGF (W) and the N-fragment of GTGF (N). The model assumes that both $\mathrm{W}$ and $\mathrm{N}$ are constitutively produced at zero-order rates $\mathrm{k}_{\mathrm{W}}$ and $\mathrm{k}_{\mathrm{N}}$, and cleared by first-order processes $\mathrm{CL}_{\mathrm{W}}$ and $\mathrm{CL}_{\mathrm{N}}$, respectively. They also distribute to peripheral tissues $\mathrm{W}_{\mathrm{T}}$ and $\mathrm{N}_{\mathrm{T}}$ at distributional clearance rates $\mathrm{CL}_{\mathrm{dW}}$ and $\mathrm{CL}_{\mathrm{dN}}$, respectively. CTGF is cleared from the tissues at the first-order clearance rate $\mathrm{CL}_{\mathrm{WT}}$. The antibody is cleared from the circulation at the first-order clearance rate $\mathrm{CL}_{\mathrm{Ab}}$ and distributes to the peripheral tissue compartment $\mathrm{Ab}_{\mathrm{T}}$ at clearance rate $\mathrm{CL}_{\mathrm{dAb}}$. Ab binds to the target species $\mathrm{W}$ and $\mathrm{N}$ at second-order rate constants $\mathrm{k}_{\mathrm{onW}}$ and $\mathrm{k}_{\mathrm{onN}}$ and forms complexes AbW and AbN, respectively. The complexes dissociate to single molecule species $\mathrm{Ab}$ and $\mathrm{W}$, and $\mathrm{Ab}$ and $\mathrm{N}$ at first-order rates $\mathrm{k}_{\mathrm{offw}}$ and $\mathrm{k}_{\mathrm{offN}}$, respectively. The complexes $\mathrm{AbW}$ and $\mathrm{AbN}$ distribute to the tissue compartments $\mathrm{AbW}_{\mathrm{T}}$ and $\mathrm{AbN}_{\mathrm{T}}$ at the first-order clearance rates $\mathrm{CL}_{\mathrm{dAbW}}$ and $\mathrm{CL}_{\mathrm{dAbN}}$, respectively. The complex $\mathrm{AbW}_{\mathrm{T}}$ is eliminated from the tissues at the first-order clearance rate $\mathrm{CL}_{\mathrm{AbWT}}$. The binding and dissociation of the antibody, CTGF, and CTGF-N in the tissues were neglected. See the Supplemental section for the mathematical description of the model.

Concentrations were expressed in $\mathrm{nM}$ units using the molecular weights of $38 \mathrm{kD}$ for CTGF, $19 \mathrm{kD}$ for N-fragment, and $75 \mathrm{kD}$ for FG-3019. The latter accounts for the two binding sites per molecule of $150 \mathrm{kD}$ IgG protein. The measurements below limit of quantification were ignored. Mean data were used for analysis. All data sets analyzed were fit simultaneously using the maximum likelihood estimator. Precision of the parameters was expressed as percent coefficient of variation. The goodness of fit was assessed by overlaying the observed data with model predictions and from the correlation coefficients between observed and predicted values for each dose group. Nonlinear regression was performed by ADAPT 5 (8).

\section{RESULTS}

\section{Pharmacokinetics of FG-3019 in Rats}

Preliminary assessment of the PK of FG-3019 in several species indicated relatively rapid clearance and a short terminal half-life (not shown). To fully characterize the PK of FG-3019, its plasma concentration in rats was measured following IV doses ranging from 0.03 to $100 \mathrm{mg} / \mathrm{kg}$ (Fig. 1). The apparent terminal phase was more rapid at low than at high dose, which is reflected in the calculated half-life $\left(\mathrm{T}_{1 / 2}\right)$ values that ranged from 1.36 days at $0.03 \mathrm{mg} / \mathrm{kg}$ to 7.31 days at $100 \mathrm{mg} / \mathrm{kg}$ (Table S1). Clearance $(\mathrm{Cl})$ decreased with increasing FG3019 dose from $90.6 \mathrm{ml} / \mathrm{kg} /$ day to $8.9 \mathrm{ml} / \mathrm{kg} /$ day over the $0.03-100 \mathrm{mg} / \mathrm{kg}$ dose range. Consistent with the dosedependent decrease in $\mathrm{Cl}$, the dose-normalized AUC $\left(\mathrm{AUC}_{\text {inf }} / \mathrm{Dose}\right)$ increased with dose level. The non-linearity 


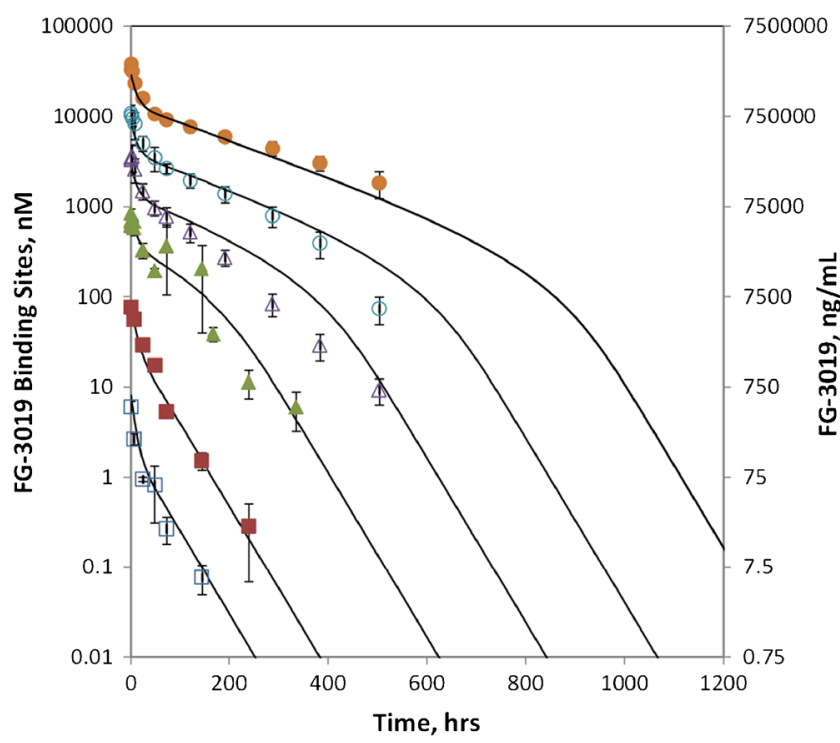

Fig. I Plasma concentration time courses for FG-30I9 in male rats. The mean plasma concentration of FG-30I 9 is expressed in $\mathrm{ng} / \mathrm{ml}$ (right axis) and in nanomolar binding site concentration ( $M W=75,000$ ) (left axis). FG-30 I9 doses administered were $0.03 \mathrm{mg} / \mathrm{kg}(n=3)$ (open squares), $0.3 \mathrm{mg} / \mathrm{kg}$ $(n=3)$ (solid squares), $3 \mathrm{mg} / \mathrm{kg}(n=9)$ (solid triangles), $10 \mathrm{mg} / \mathrm{kg}(n=6)$ (open triangles), $30 \mathrm{mg} / \mathrm{kg}(n=6)$ (open circles) and $100 \mathrm{mg} / \mathrm{kg}(n=6)$ (solid circles). Error bars reflect standard deviations. Solid curves are from fits of the data using a pharmacokinetic model.

of the rat pharmacokinetic parameters with the dose of FG3019 indicates a role of a saturable process in the elimination mechanism.

\section{Effect of FG-3019 on Circulating CTGF in Rats}

Endogenous CTGF plasma concentrations were essentially unchanged upon dosing with FG-3019. Pre-dose concentrations were uniformly below the $5.6 \mathrm{ng} / \mathrm{ml}$ lower limit of quantitation. For the high dose group there was only one time point $(0.5 \mathrm{~h})$ for which all three test animals had quantifiable $\mathrm{W}$ CTGF concentrations, averaging $10 \pm 3 \mathrm{ng} / \mathrm{ml}$ (not shown). In contrast, plasma concentrations of CTGF-N detected by the N+W-CTGF assay rose substantially after dosing with FG-3019 (Fig. 2). Both the maximum level and the time to maximum $\mathrm{N}+\mathrm{W}$-CTGF level were dose dependent, with $\mathrm{C}_{\max } \mathrm{N}+\mathrm{W}$-CTGF concentrations of 32,77 and $197 \mathrm{ng} / \mathrm{ml}$, and $\mathrm{T}_{\max }$ times of 24,48 and $120 \mathrm{~h}$ for the 10,30 and $100 \mathrm{mg} / \mathrm{kg}$ FG-3019 doses, respectively. CTGF concentrations for the $0.03,0.3$ and $3 \mathrm{mg} / \mathrm{kg}$ dose level were not determined. Since CTGF-whole concentrations were unaffected by FG-3019 dosing, the increase in signal measured by the N+ W-CTGF assay corresponds to accumulation in the plasma of CTGF-N. It should be noted that the CTGF-N in circulation after dosing with FG-3019 is expected to be mostly complexed with FG-3019 due to the excess concentration of circulating antibody.

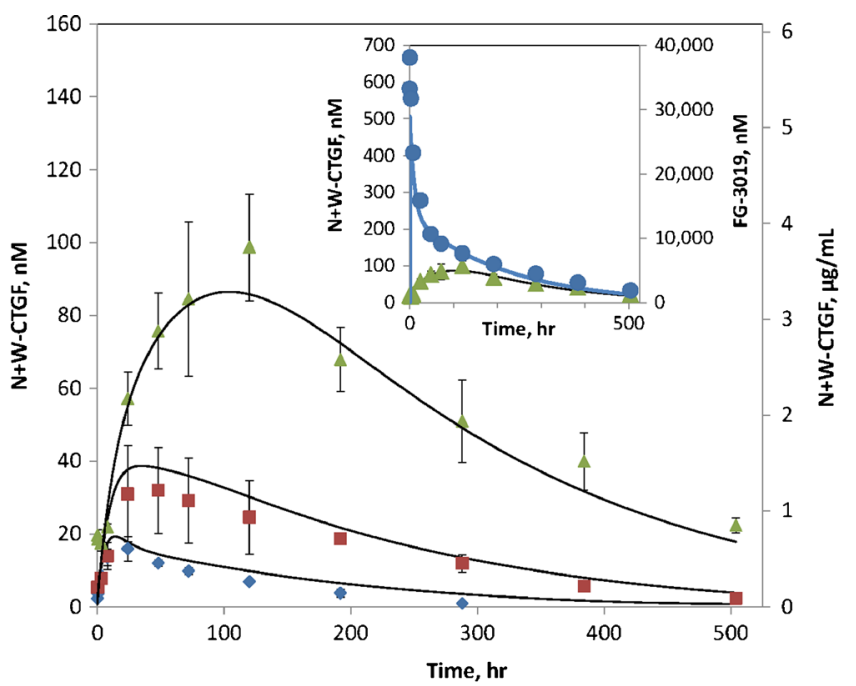

Fig. 2 Rat plasma concentrations of endogenous CTGF following administration of FG-3019. Male rats were administered FG-3019 at $10 \mathrm{mg} / \mathrm{kg}$ (diamonds), $30 \mathrm{mg} / \mathrm{kg}$ (squares) or $100 \mathrm{mg} / \mathrm{kg}$ (triangles). CTGF was measured using the N+W-CTGF assay as described in the text. Error bars are standard deviations of the means of three animals. Concentrations of intact CTGF measured with the W-CTGF assay are below $5 \mathrm{ng} / \mathrm{ml}$ and are not shown. Solid curves are fits obtained from pharmacokinetic modeling. Inset: concentrations of FG-3019 in rats dosed at $100 \mathrm{mg} / \mathrm{kg}$ (circles,right axis) are shown with the corresponding CTGF concentrations (triangles, left axis).

\section{Pharmacokinetics of CTGF}

The pharmacodynamic effect of FG-3019 on circulating CTGF-N concentration raised questions about the source of plasma CTGF-N, the mechanism for the post FG-3019 dose increase, and the absence of this effect for CTGF-W. To begin to address these questions and develop a PK/PD model for FG-3019 we decided to evaluate the kinetics of CTGF itself. We found that disappearance of recombinant human CTGF$\mathrm{N}$ from the blood following an intravenous dose (Fig. 3) was rapid and biphasic, with average terminal phase half-life of $43.5 \mathrm{~min}$. The initial phase of disappearance of plasma CTGF-whole following intravenous injection was too fast to allow for non-compartmental assessment. The terminal phase had a half-life of $3.3 \mathrm{~min}, 13$-fold faster than the terminal phase half-life of CTGF-N. Thus, the elimination kinetics of both forms of CTGF were clearly much faster than the kinetics observed for FG-3019.

\section{Effect of Recombinant Human CTGF on FG-3019 Pharmacokinetics in Rats}

In rats, rhCTGF-N is eliminated from circulation rapidly, but the endogenous N-fragment of CTGF accumulates after dosing with FG-3019. This suggests that accumulation may be due to much slower elimination kinetics for the complex of CTGF-N with FG-3019 than for free CTGF-N. Similar accumulation of other soluble target/antibody complexes has been reported $(9,10)$. In contrast, the intact form of 

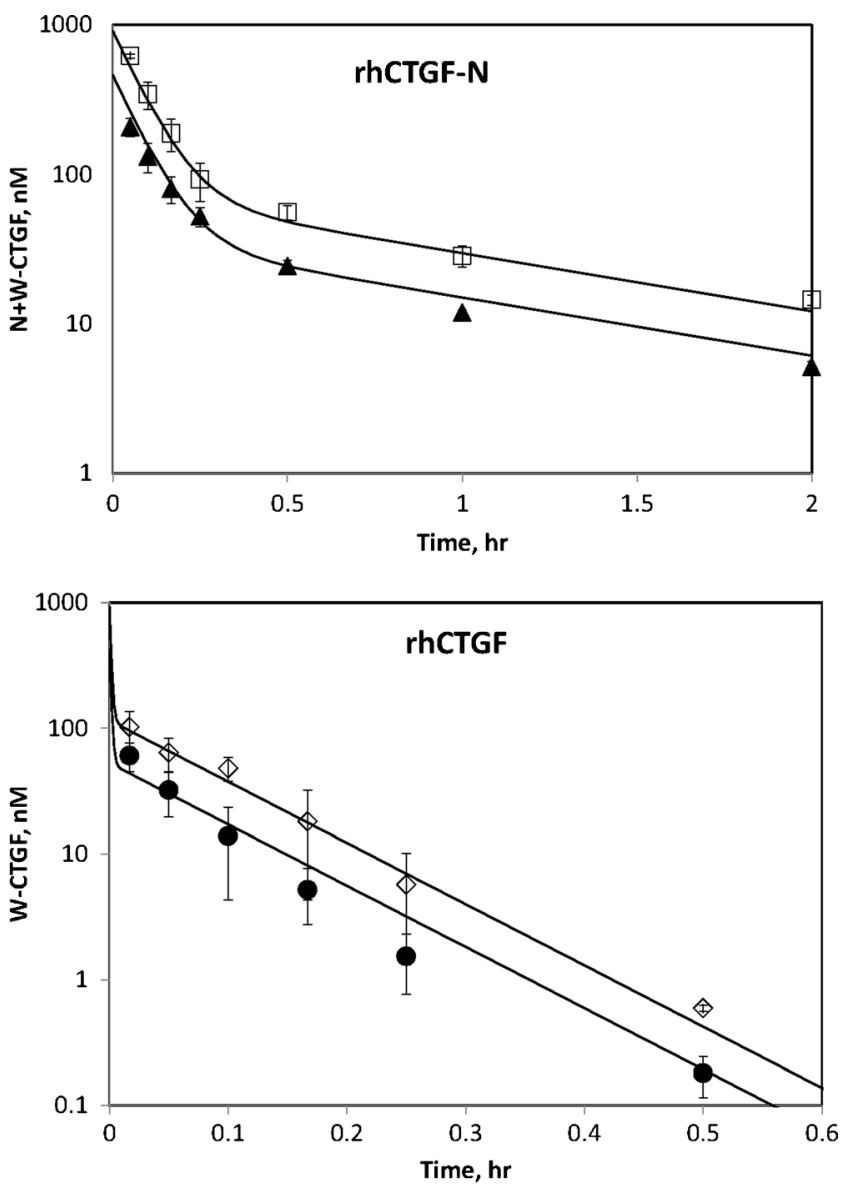

Fig. 3 Plasma Concentration Time Courses of Recombinant Human CTGF in Male Rats. Top panel: rhCTGF-N was administered at $0.38 \mathrm{mg} / \mathrm{kg}$ (solid triangles) and $0.8 \mathrm{mg} / \mathrm{kg}$ (open squares). CTGF was measured using the $\mathrm{N}+$ W-CTGF assay. Bottom panel: rhCTGF was administered at $0.76 \mathrm{mg} / \mathrm{kg}$ (solid circles) and $1.6 \mathrm{mg} / \mathrm{kg}$ (open diamonds). CTGF was measured using the WCTGF assay. Error bars are standard deviations from 3 animals per group. Solid curves were obtained by a pharmacokinetic model.

endogenous CTGF did not accumulate in the circulation after dosing with FG-3019, despite the affinity of the antibody for CTGF $\left(\mathrm{K}_{\mathrm{d}}=0.1-0.2 \mathrm{nM}\right.$, unpublished radioimmunoassay results). This indicates either that the rate of production of CTGF-whole into the circulation is too low to result in significant accumulation of CTGF/FG-3019 complexes, or the complex formed between CTGF and FG-3019 is eliminated too rapidly to allow for significant accumulation. To evaluate these two possibilities we chose to estimate the rate of elimination of FG-3019/CTGF complexes by determining the effect of co-administered CTGF on FG-3019 pharmacokinetics. Administration of CTGF-N to rats previously dosed with FG3019 had no significant effect on the level of FG-3019, or the rate of disappearance of FG-3019 from the circulation (Fig. 4). However, co-administration of intact CTGF had a profound impact on FG-3019 kinetics.

As shown in Fig. 4, dosing with CTGF caused an extremely rapid decrease of plasma FG-3019 concentration. This effect was CTGF dose-dependent, such that 23\%, 50\% and 93\% decreases in FG-3019 concentration 6 min after injecting CTGF were seen at the low, middle and high CTGF:FG3019 ratios, respectively. After the initial rapid drop in FG3019 concentration the elimination rate of FG-3019 was indistinguishable from the rate of FG-3019 elimination in animals that were not injected with CTGF. It appeared that the injected rhCTGF was complexing with FG-3019 and this complex was then eliminated from the blood in the same rapid fashion observed for rhGTGF in the absence of FG-3019. Interestingly, the impressive decrease in FG-3019 concentration triggered by administration of CTGF in 2:1 stoichiometry to FG-3019 was followed six hours later by a small, but reproducible increase in FG-3019 concentration. This may have resulted from dissociation of the antibody from CTGF, or from antibody recycling.

CTGF has been reported to bind to the receptor LRP1, which we thought might be responsible for the rapid elimination of CTGF and CTGF/FG-3019 complexes from the blood. We therefore tested the effect of an inhibitor of LRP1 binding activity, the receptor associated protein (RAP), on CTGF's clearing activity toward FG-3019 (7,11). Coadministration of $9 \mathrm{mg}$ RAP per animal significantly reduced the impact of CTGF on FG-3019 elimination kinetics, consistent with involvement of LRP-1 (and/or LRP2/megalin) in the CTGF mediated antibody clearance (Fig. 5).

The kinetic data for FG-3019, rhCTGF and rhCTGF-N together with the effect of CTGF on FG-3019 PK and the pharmacodynamic effect of FG-3019 on CTGF concentrations indicate that when CTGF and CTGF-N are secreted from tissues they share different fates upon encountering FG-3019. CTGF-N binds to FG-3019 and takes on the relatively slow elimination kinetics of free antibody while intact CTGF binds to FG-3019 and causes the antibody to be rapidly eliminated, presumably through the same pathway as free CTGF. To explore this model further we defined a kinetic model and fit the relevant kinetic data as described below.

\section{Pharmacokinetic Modeling of Target-Mediated Elimination of FG-3019}

A pharmacokinetic model (Fig. 6) was designed to account for the data presented above. For simplicity, we elected to confine antibody/CTGF binding reactions in this model to the central compartment (i.e. plasma), with uptake and elimination of the complex between antibody and CTGF through a tissue compartment. This is in distinction to a model where antibody distributes into tissues, binds to locally produced CTGF, and then undergoes target-mediated elimination as an antibody/ CTGF complex without returning to the central compartment. In this model, the following steps constitute the targetmediated clearance pathway: binding of antibody ( $\mathrm{Ab})$ to CTGF (W) in the central compartment, distribution of the Ab-CTGF complex to tissues $\left(\mathrm{AbW}_{\mathrm{T}}\right)$ at rate $\mathrm{CL}_{\mathrm{dAbW}}$, 
Fig. 4 Effect of Co-administered CTGF on FG-30। 9

pharmacokinetics. The amount of FG-3019 (expressed as percent of initial level remaining) is shown versus time after administration of CTGF or other components. Components co-administered were: buffer (open circles); CTGF-N (solid diamonds); CTGF at 0.5: I molar ratio with FG-30 I 9 (solid squares); CTGF at I: I molar ratio with FG-30I 9 (solid triangles); CTGF at 2:I molar ratio with FG3019 (solid circles). FG-30I9 was administered at $-10 \mathrm{~min}$. CTGF was added at time zero.Error bars reflect the standard deviation of mean values.

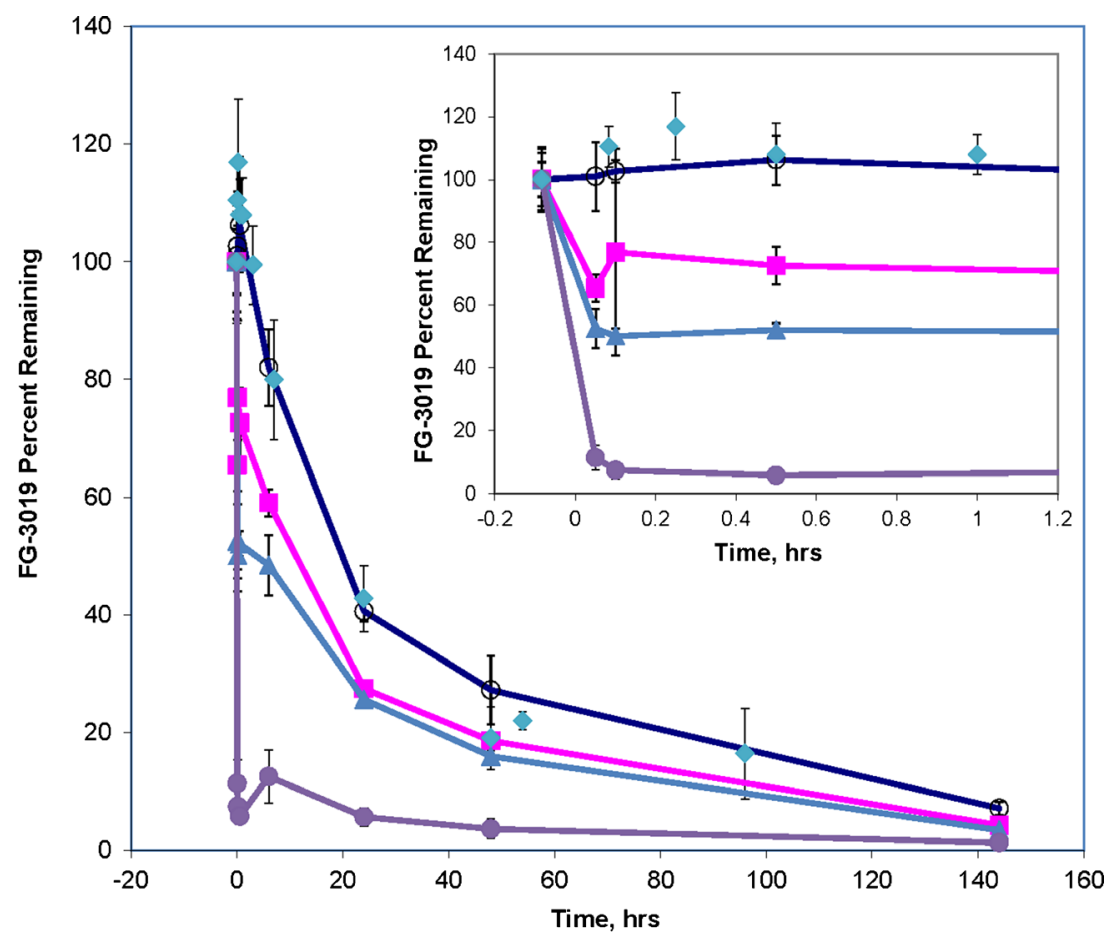

followed by elimination of the Ab-CTGF complex from the tissue compartment at a rate $\mathrm{CL}_{\mathrm{AbWT}}$. The time course for the initial rapid phase of rhCTGF disappearance (Fig. 3) could not be fit due to lack of data points. Therefore, the $t=0$ plasma concentration of CTGF was set equal to the extrapolated $t=0$ concentration from the $\mathrm{N}$-fragment kinetics analysis, and the initial rapid phase for CTGF was forced to be very rapid in the modeling by setting $\mathrm{CL}_{\mathrm{W}}=10 \mathrm{~L} / \mathrm{h}$.

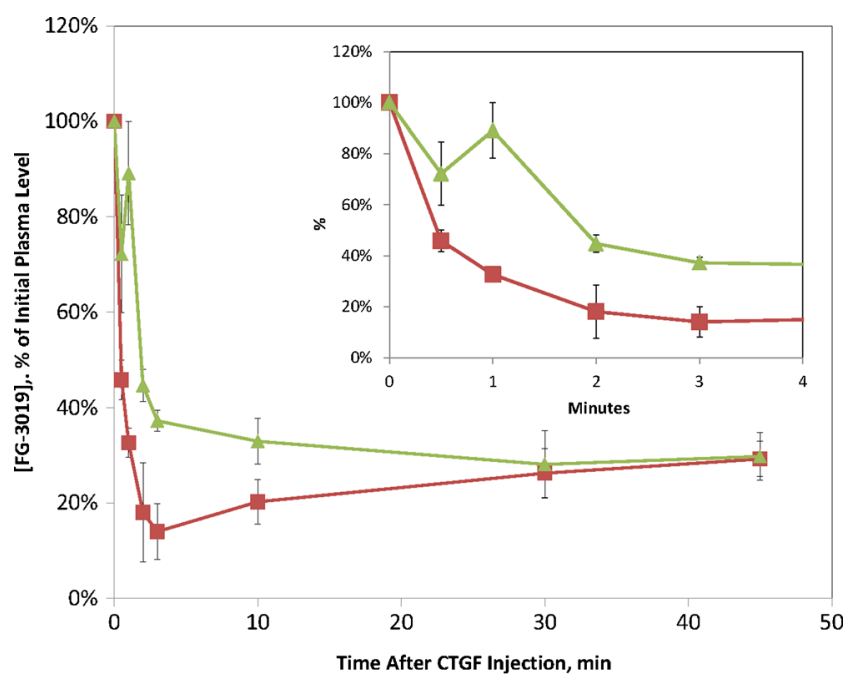

Fig. 5 Effect of Co-administered RAP on CTGF mediated elimination of FG3019. The level of FG-3019 (expressed as percent of initial level) is shown versus time after administration of CTGF (squares), or RAP ( 9 mg) immediately followed by CTGF (triangles). CTGF was administered at a 2:I molar ratio to FG-3019. CTGF or (RAP + CTGF) was administered at time zero, $10 \mathrm{~min}$ after FG-30 I 9. Error bars reflect standard deviation of mean values.
The PK model involved a large number of parameters that could not be resolved from the available data. To avoid problems with the model identifiability, some parameters were assumed to be equal and some processes were considered as very rapid. The distributional clearances for $\mathrm{W}$ and the complex AbW were assumed to be fast and set as $\mathrm{CL}_{\mathrm{dW}}=\mathrm{CL}_{\mathrm{dAbW}}=10 \mathrm{~L} / \mathrm{h}$ with $\mathrm{V}_{\mathrm{AbWT}}=\mathrm{V}_{\mathrm{WT}}$. This assumption was based upon the observation that exogenously added CTGF resulted in very rapid elimination of FG-3019 from circulation (Fig. 4) and the very rapid clearance of rhCTGF (Fig. 3). The binding of FG-3019 to target was considered rapid. To avoid introducing a rapid binding approximation that would require overly complex equations (12) we enforced this assumption by setting the dissociation rate constants $\mathrm{k}_{\text {offW }}=\mathrm{k}_{\text {offN }}=100 \mathrm{~h}^{-1}$. We assumed that the complex of FG3019 bound to N-fragment follows the distribution kinetics of free FG-3019, $\mathrm{CL}_{\mathrm{dAbN}}=\mathrm{CL}_{\mathrm{dAb}}$ and $\mathrm{V}_{\mathrm{AbNT}}=\mathrm{V}_{\mathrm{AbT}}$. This assumption was based upon the observation that exogenously added CTGF-N did not result in very rapid elimination of FG3019 from circulation (Fig. 4). The tissue clearance rates of $\mathrm{W}$ and $\mathrm{AbW}$ were set equal, $\mathrm{CL}_{\mathrm{WT}}=\mathrm{CL}_{\mathrm{AbWT}}$. Also the clearance rates of $\mathrm{W}$ and $\mathrm{N}$ from the plasma were assumed to be the same, $\mathrm{CL}_{\mathrm{W}}=\mathrm{CL}_{\mathrm{N}}$. While this assumption is not strictly correct based on the data shown in Fig. 3, the plasma clearance of $\mathrm{W}$ and $\mathrm{N}$ are so much faster than free $\mathrm{Ab}$ that the difference between $\mathrm{CL}_{\mathrm{W}}$ and $\mathrm{CL}_{\mathrm{N}}$ should not matter. The non-target mediated clearance rates from the plasma compartment of antibody-bound forms of CTGF were set equal to the free antibody clearance rate, $\mathrm{CL}_{\mathrm{Ab}}=\mathrm{CL}_{\mathrm{AbW}}=\mathrm{CL}_{\mathrm{AbN}}$. It was also assumed that endogenous and recombinant forms of CTGF are kinetically identical. 


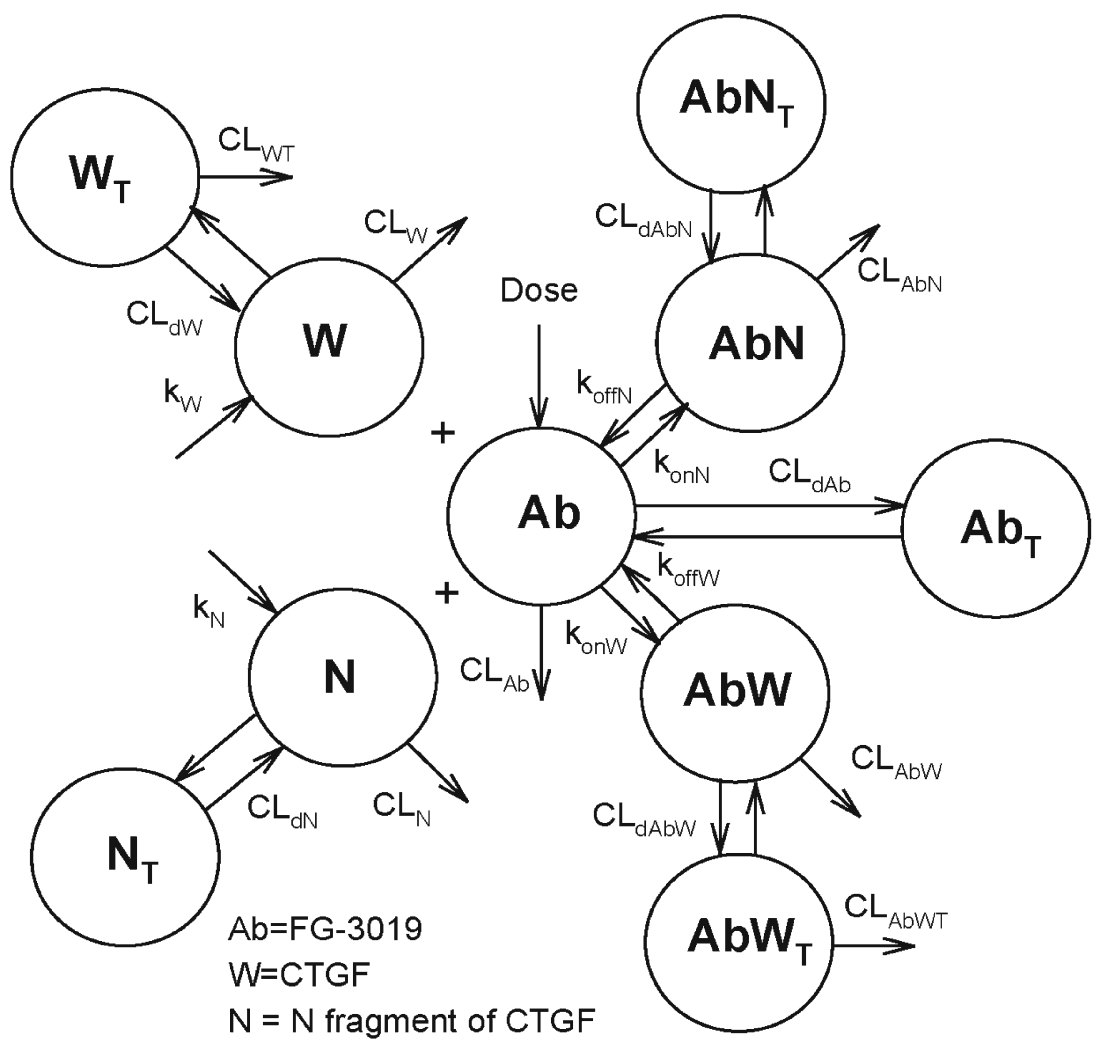

Fig. 6 Schematic diagram of the PK model of target mediated disposition of FG-3019. The model assumes that both CTGF (W) and CTGF-N (N) are constitutively produced at zero-order rates $\mathrm{k}_{w}$ and $\mathrm{k}_{\mathrm{N}}$, and cleared by first-order processes $C \mathrm{~L}_{w}$ and $C \mathrm{~L}_{N}$, respectively. They also distribute to peripheral tissues $W_{T}$ and $N_{T}$ at distributional clearance rates $C L_{d W}$ and $C L_{d N}$, respectively. CTGF is cleared from the tissues at the first-order clearance rate $C L_{W T}$. The antibody, FG-30 I 9, is cleared from the circulation at the first-order clearance rate $C L_{A b}$ and distributes to the peripheral tissue compartment $A b_{T}$ at clearance rate $C L_{d A b}$. $A b$ binds to the target species $W$ and $N$ at second-order rate constants $k_{o n} w$ and $k_{o n} N$ and forms complexes $A b_{W}$ and $A b_{N}$, respectively. The complexes dissociate to single molecule species $A b$ and $W$, and $A b$ and $N$ at first-order rates $k_{\text {offw }}$ and $k_{\text {offN }}$, respectively. The complexes $A b_{W}$ and $A b_{N}$ distribute to the tissue compartments $A b_{W T}$ and $A b_{N T}$ at the first-order clearance rates $C L_{d A b W}$ and $C L_{d A b N}$, respectively. The complex $A b b_{W T}$ is eliminated from the tissues at the first-order clearance rate $\mathrm{CL}_{\mathrm{AbW}}$. The binding and dissociation of the antibody, CTGF, and CTGF-N in the tissues were neglected.

Three datasets were simultaneously analyzed. The first data set comprised the observed CTGF plasma concentrations following injections of rhCTGF or GTGF-N (Fig. 3). The assays do not detect the endogenous rat CTGF; therefore, both $\mathrm{W}_{0}$ and $\mathrm{N}_{0}$ were set to 0 . The second data set comprised the plasma concentrations of FG-3019 (total of free and CTGF-complexed forms) following administration of the antibody (Fig. 1). Plasma samples for measurements were collected for up to $504 \mathrm{~h}$. The third data set was comprised of the total combined plasma concentrations of endogenous CTGF-N plus GTGF (free and antibody-bound) following injection of FG-3019 (Fig. 2). We did not include data for the effect of exogenous rhCTGF on FG-3019 kinetics (Fig. 4) because the model treats FG-3019 as a monovalent species with $75 \mathrm{kDa}$ molecular weight, whereas rhCTGF added to FG-3019 at stoichiometric ratios will form significant amounts of complex having a 2-to-1 ratio of rhCTGF to the bivalent $150 \mathrm{kDa}$ FG-3019 molecule. We also did not include data for the inhibition by RAP of the CTGF clearing effect (Fig. 5) because we lacked data on RAP kinetics in rat.
Model parameters obtained from data fitting are listed in Table I and graphical results are shown as solid curves superimposed onto the experimental data in Figs. 1, 2 and 3. The model fits of the antibody plasma concentration (combined free antibody and antibody/CTGF complexes) shown in Fig. 1 exhibit patterns characteristic of target-mediated disposition (13). The initial phase corresponds to rapid tissue distribution. For high doses, this is followed by a plateau due to saturation of the target-mediated clearance pathway, which is followed by a faster terminal elimination phase as the targetmediated pathway becomes predominant at lower antibody concentration (14). The fits of combined plasma concentrations for species detected by the $\mathrm{N}+\mathrm{W}-\mathrm{CTGF}$ assay (Fig. 2) are dominated by the total of CTGF-N and antibody/CTGF$\mathrm{N}$ complex. Calculated CTGF is included in the sum since the immunoassay detects this species, but concentrations of GTGF are in fact negligible. The combined concentration of free and bound CTGF-N starts at a low baseline value, reaches a peak and returns to the baseline. Such behavior is characteristic for target-mediated drug disposition when the clearance of the drug-target complex is slower than the 
Table I Calculated Model Parameter Values and Their Coefficients of Variation

\begin{tabular}{|c|c|c|}
\hline Parameter & Estimate & CV\% \\
\hline$V, L$ & 0.01512 & 6.3 \\
\hline$C L_{w}, L / h$ & 0.09243 & 3.7 \\
\hline$V_{W T}, L$ & 0.1160 & 13.0 \\
\hline ClwT, L/h & 1.380 & 9.5 \\
\hline $\mathrm{CL}_{\mathrm{dW}}, \mathrm{L} / \mathrm{h}$ & 10 & FIXED \\
\hline$C L_{N}, L / h$ & $0.09243^{a}$ & NA \\
\hline$V_{N T,} L$ & 0.04458 & 11.5 \\
\hline$C L_{d N}, L / h$ & 0.07998 & 9.4 \\
\hline$K_{D W}, n M$ & 23.97 & 18.0 \\
\hline$K_{D N}, n M$ & 51.21 & 15.0 \\
\hline$k_{\text {offW }}, h^{-1}$ & 100 & FIXED \\
\hline$k_{\text {offN }}, h^{-1}$ & 100 & FIXED \\
\hline $\mathrm{C}_{\text {wo }}, \mathrm{nM}$ & $0.0259 \mid$ & 15.6 \\
\hline$C_{\text {NO }}, n M$ & 0.6572 & 10.6 \\
\hline $\mathrm{CL}_{A b}, \mathrm{~L} / \mathrm{h}$ & 0.0001321 & 6.4 \\
\hline$V_{A b T}, L$ & 0.01363 & 12.5 \\
\hline$C L_{d A b}, L / h$ & 0.0005692 & 27.7 \\
\hline$C_{\text {AbW, }}, \mathrm{L} / \mathrm{h}$ & $0.0001331^{b}$ & NA \\
\hline$C L_{d A b W}, L / h$ & 10 & FIXED \\
\hline $\mathrm{CL}_{\mathrm{AbN}}, \mathrm{L} / \mathrm{h}$ & $0.0001321^{b}$ & NA \\
\hline$C L_{d A b N}, L / h$ & $0.0005692^{c}$ & NA \\
\hline $\mathrm{CL}_{\mathrm{AbWT}}, \mathrm{L} / \mathrm{h}$ & $1.380^{\mathrm{d}}$ & NA \\
\hline $\mathrm{kW}_{\mathrm{W}} \mathrm{nmol} / \mathrm{h}$ & $0.03382^{e}$ & 13.5 \\
\hline $\mathrm{k}_{\mathrm{N}}, \mathrm{nmol} / \mathrm{h}$ & $0.06075^{e}$ & 10.2 \\
\hline \multicolumn{3}{|c|}{${ }^{\mathrm{a}} \mathrm{CL}_{\mathrm{N}}=\mathrm{C} \mathrm{L}_{\mathrm{W}}$} \\
\hline \multicolumn{3}{|c|}{${ }^{\mathrm{b}} \mathrm{CL}_{\mathrm{Ab}}=\mathrm{CL}_{\mathrm{AbW}}=\mathrm{CL}_{\mathrm{AbN}}$} \\
\hline \multicolumn{3}{|c|}{${ }^{c} C L_{d A b N}=C L_{d A b}$} \\
\hline \multicolumn{3}{|c|}{${ }^{\mathrm{d}} \mathrm{CL}_{\mathrm{AbWT}}=\mathrm{CL}_{W T}$} \\
\hline
\end{tabular}

clearance of the free target (15). Only the lowest dose data at late time points were slightly over-predicted with $r^{2}=0.94$, with the remaining data well described by the model $\left(r^{2}=0.97-0.98\right)$.

The estimated central volume $\mathrm{V}=50.4 \mathrm{ml} / \mathrm{kg}$ (for a $0.3 \mathrm{~kg}$ animal) is close to the reported rat plasma volume of $39.6 \mathrm{ml} /$ $\mathrm{kg}$ (16). The estimated central compartment clearance rate for FG-3019, $\mathrm{CL}_{\mathrm{Ab}}$, is $0.1355 \mathrm{ml} / \mathrm{h}(0.45 \mathrm{ml} / \mathrm{h} / \mathrm{kg}$ for a $0.3 \mathrm{~kg}$ animal) compared with a published plasma clearance rate of $0.8 \mathrm{ml} / \mathrm{h} / \mathrm{kg}$ for ${ }^{125}$ I-labeled human $\mathrm{IgG}$ in rats (17). Estimated baseline plasma concentrations of CTGF and CTGF-N were 0.0259 and $0.657 \mathrm{nM}(0.98$ and $12.5 \mathrm{ng} / \mathrm{ml})$, respectively, whereas the measured concentrations at baseline were below the LLOQ of $5.6 \mathrm{ng} / \mathrm{ml}$ for CTGF and below the LLOQ of $11 \mathrm{ng} / \mathrm{ml}$ for the sum of CTGF and CTGF-N. Calculated production rates of CTGF and CTGF-N $\left(\mathrm{k}_{\mathrm{W}}\right.$ and $\mathrm{k}_{\mathrm{N}}$ ) were 0.034 and $0.061 \mathrm{nmol} / \mathrm{h}$, respectively. Since CTGF-N is derived from CTGF, the total estimated rate of CTGF production per animal is the sum of these rates,
$0.095 \mathrm{nmol} / \mathrm{h}$, which is equivalent to $0.29 \mathrm{mg} / \mathrm{kg} / \mathrm{day}$. The model-estimated antibody binding constants $\left(\mathrm{K}_{\mathrm{d}}\right)$ for CTGF and CTGF-N were 24 and $51 \mathrm{nM}$, respectively. The value for CTGF is 120 -fold larger than the $\mathrm{K}_{\mathrm{d}}$ obtained from in vitro studies employing ${ }^{125}$ I-labeled CTGF (unpublished data). The value for CTGF-N is 3-fold larger than measured by a surface plasmon resonance kinetic method. However, similar discrepancies have been reported for other antibodies, suggesting that in vitro $\mathrm{K}_{\mathrm{d}}$ measurements in buffer using radioiodinated human CTGF overestimate the effective in vivo binding affinity of endogenous rat GTGF (18).

\section{Dose-Dependence of Target-Mediated Elimination}

The degree to which target-mediated antibody elimination is responsible for the overall clearance of FG-3019 was estimated by simulating the elimination rate of FG-3019/CTGF complex from the tissue compartment over time and comparing this to the simulated combined central compartment elimination rates for all FG-3019 containing species. The integrated areas under the simulated curves correspond to the amount of antibody eliminated. Figure 7 shows the percentage of antibody that is cleared by the target-mediated pathway. For doses at or below $3 \mathrm{mg} / \mathrm{kg}$, target-mediated clearance is the major pathway for antibody elimination. In $300 \mathrm{~g}$ rats, an IV dose of $3 \mathrm{mg} / \mathrm{kg}$ FG-3019 corresponds to a $\mathrm{C}_{\max }$ plasma concentration of approximately $1 \mu \mathrm{M}$. Thus, at plasma concentrations below $1 \mu \mathrm{M}$, target-mediated elimination dominates FG-3019 clearance, while at higher concentrations it contributes less. At the highest dose tested $(100 \mathrm{mg} / \mathrm{kg})$, $7.4 \%$ of the FG-3019 dose was eliminated by the targetmediated pathway. In a subject with disease that may be producing and shedding more CTGF, targetmediated elimination would be expected to play a larger role in the clearance of FG-3019. Similarly,

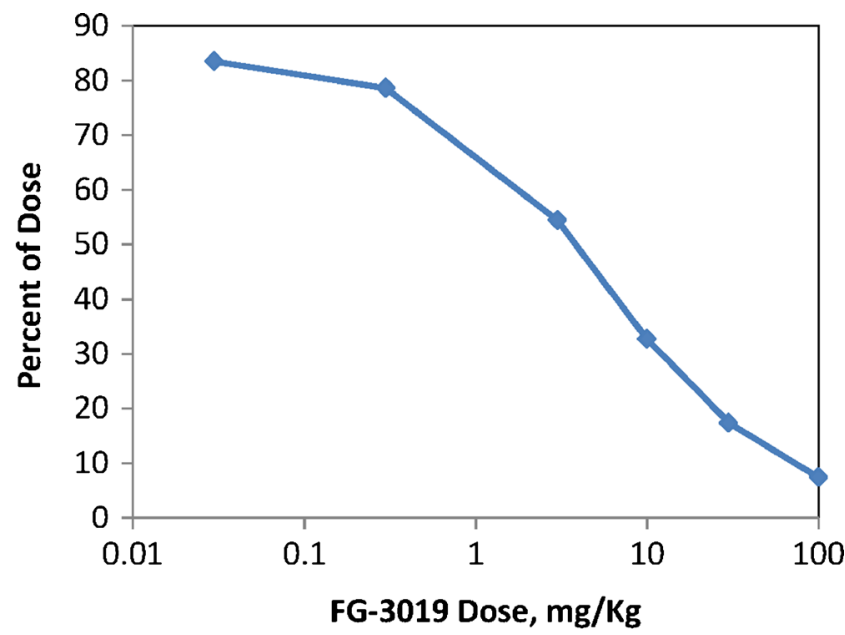

Fig. 7 Dose-dependence of target-mediated elimination of FG-3019. The percent target-mediated elimination was estimated by modeling rates of elimination of FG-301 9 from tissue and central compartments. 
the terminal elimination rate would be expected to be higher, in proportion to the increased rate of CTGF shedding.

\section{Rat Tissue Distribution of ${ }^{125}$ I-FG-3019 and Effect of CTGF}

The complex between FG-3019 and CTGF is rapidly eliminated from the blood. To identify the site(s) where rhCTGF causes FG-3019 to be redistributed, radio-iodinated FG-3019 ([ $\left.\left.{ }^{125} \mathrm{I}\right]-\mathrm{FG}-3019\right)$ was prepared and examined for its distribution in rat tissues in the absence and presence of rhCTGF using quantitative whole body autoradiography (QWBA).

Gamma counting of urine, feces and cage wipe materials from animals dosed with $\left[{ }^{125} \mathrm{\Gamma}\right]-\mathrm{FG}-3019$ alone showed that $0.8 \%, 1.7 \%$ and $23.7 \%$ of the dosed radioactivity was excreted from animals euthanized at 2, 6 and 24-h post dose, respectively. Concentrations of $\left[{ }^{125} \mathrm{I}\right]-\mathrm{FG}-3019$ determined by gamma counting in blood and plasma are shown in Table II. $\left[{ }^{125} \mathrm{I}\right]$-FG-3019 concentrations were approximately half as high in the blood as plasma, indicating that $\left[{ }^{125}\right.$ I]-FG-3019 is restricted to the non-cellular portion of blood. The rat dosed with CTGF had 6.2- and 3.9-fold lower [ ${ }^{125}$ ] -FG-3019 concentrations in plasma and blood, respectively, than the corresponding rat which was not dosed with CTGF. This large decrease in $\left[{ }^{125} \mathrm{~T}\right]-\mathrm{FG}-3019$ concentration is consistent with the effect of CTGF on plasma concentrations of nonradioactive FG-3019 observed in the studies described previously. The blood/plasma ratio (0.708) in the rat dosed with CTGF was higher than in the animals not dosed with CTGF, suggesting that the CTGF/FG-3019 complex associates slightly more with the cellular components of blood than FG-3019 in the absence of CTGF.

Whole-body autoradiograms showing patterns of radioactivity distribution in tissues from rats euthanized at $0.25 \mathrm{~h}$ are illustrated in Fig. 8. Tissue concentrations of radioactivity are listed in Table II. Note that animals were not perfused prior to QWBA, so tissue concentrations of radioactivity include radioactivity in the blood content of each tissue. Radioactivity was widely distributed in rats dosed with $\left[{ }^{125}\right.$ I]-FG-3019 alone (rat \#1, 3, 4 and 5). The highest concentrations of radioactivity $(>50 \mu \mathrm{g}$ equivalent/g) were found in blood, lung and adrenal medulla. Concentrations in the central nervous system, bone, skeletal muscle, white fat, and eye lens were the lowest of all tissues $(\leq 6.2 \mu \mathrm{g}$ equiv/g). Most tissues had relatively high concentrations of drug-derived radioactivity at $24 \mathrm{~h}$ post dose and concentrations ranged from 53.4 $\mu \mathrm{g}$ equivalent/g in blood to $2.4 \mu \mathrm{g}$ equivalent/g in white fat. The tissues of the central nervous system, seminal vesicles, skeletal muscle, eye lens, urinary bladder, and the contents of the alimentary canal had concentrations of radioactivity below the lower limit of quantitation at $24 \mathrm{~h}$ post-dose.

Tissue concentrations of radioactivity in the rat given CTGF $10 \mathrm{~min}$ after the dose of $\left[{ }^{125} \mathrm{~T}\right]-\mathrm{FG}-3019$ were very different from those dosed with $\left[{ }^{125} \Pi\right]-F G-3019$ alone. Most notable were the large fold increases in liver (5.87-fold), adrenal cortex (10-fold), adrenal medulla (3.07-fold), and kidney cortex (1.88-fold). The tissue-to-blood radioactivity concentration ratios for liver, adrenal cortex, adrenal medulla and kidney cortex in the rat co-administered CTGF were 8.3, 10.7, 5.7 and 2.23, respectively, indicating extensive uptake of the $\left[{ }^{125}\right.$ I] -FG-3019/CTGF complex by these organs. Bone marrow and spleen also had high tissue-to-blood concentration ratios of 1.44 and 1.29 , respectively, in the rat treated with CTGF. In summary, co-administration of CTGF causes FG-3019 to distribute out of the blood and predominantly into liver, adrenal and kidney.

\section{Immunohistochemical Analysis}

To explore which cells might take up CTGF/antibody complexes, immunohistochemical analysis was conducted on several tissues (liver, kidney, adrenal, spleen, lung and heart) from rats administered FG-3019 alone or with CTGF. In animals treated with FG-3019 alone no staining for FG-3019 was seen in any of the organs $15 \mathrm{~min}$ after injection, which is consistent with the slow penetration of IgG into tissues and the removal of blood by perfusion prior to tissue fixation (not shown). In animals treated with FG-3019 in combination with CTGF, staining for FG-3019 was observed in the sinusoids of adrenal glands and liver and lining the capillaries of kidney glomeruli (Fig. 9). Sparse staining was also observed in the red pulp of the spleen. In contrast with the results in liver, adrenal glands, kidney and spleen, co-administration of rhCTGF did not modify FG-3019 distribution to the heart and lung: no staining for FG-3019 was seen in the heart and lung of animals treated with FG-3019 only, or with a combination of FG-3019 and CTGF (not shown).

\section{DISCUSSION}

In rats, as well as monkeys and humans (data not shown), FG3019 exhibited non-linear, saturable kinetics where higher doses of FG-3019 resulted in longer apparent terminal halflives, slower clearance and disproportionately higher plasma exposure (19). Apparent terminal half-life in rats was maximal (7.67 days) and clearance reached a minimum of $8.38 \mathrm{ml} /$ day $/ \mathrm{kg}$ at the highest tested dose level, suggesting a saturable elimination pathway for FG-3019. This PK behavior is consistent with participation of a target-mediated pathway in the elimination of FG-3019. The potential for CTGF to mediate antibody clearance was confirmed in co-administration experiments in which exogenously added rhCTGF rapidly (<3 min) and stoichiometrically eliminated FG-3019 from plasma. The rapidity of this plasma elimination is consistent with the $\mathrm{PK}$ of CTGF, which was also very rapidly eliminated from plasma 
Table II Tissue Concentrations of Radioactivity After [ $\left.{ }^{125} \mathrm{l}\right]-\mathrm{FG}-3019$ Administration

\begin{tabular}{|c|c|c|c|c|c|c|c|}
\hline \multirow[t]{2}{*}{ Tissue type } & \multirow[t]{2}{*}{ Tissue } & \multicolumn{5}{|c|}{ Mean - $\mu g$ equivalents/g tissue } & \multirow[b]{2}{*}{$\begin{array}{l}\text { Ratio } \\
\text { Rat 2/Rat I }\end{array}$} \\
\hline & & $\begin{array}{l}\text { Rat \# I } \\
0.25 \text { h }\end{array}$ & $\begin{array}{l}\text { Rat \# 2 }{ }^{\mathrm{a}} \\
0.25 \mathrm{~h}\end{array}$ & $\begin{array}{l}\text { Rat \# } 3 \\
2 \mathrm{~h}\end{array}$ & $\begin{array}{l}\text { Rat \# } 4 \\
6 \mathrm{~h}\end{array}$ & $\begin{array}{l}\text { Rat \# } 5 \\
24 \mathrm{~h}\end{array}$ & \\
\hline \multirow[t]{5}{*}{ Vascular/lymphatic } & Blood (by QWBA) & 113.2 & 24.0 & 105.9 & 124.7 & 53.4 & 0.21 \\
\hline & Bone marrow & 35.6 & 34.5 & 25.1 & 38.9 & 19.5 & 0.97 \\
\hline & Lymph node & 6.4 & 4.4 & 19.0 & 14.4 & 9.8 & 0.70 \\
\hline & Spleen & 27.0 & 30.9 & 24.5 & 26.3 & 15.5 & 1.15 \\
\hline & Thymus & 10.4 & 2.8 & 9.7 & 11.9 & 7.7 & 0.27 \\
\hline \multirow[t]{6}{*}{ Excretory/metabolic } & Bile (in duct) & $\mathrm{NI}$ & 52.3 & 115.5 & $\mathrm{NI}$ & 21.3 & NC \\
\hline & Kidney cortex & 29.8 & 56.1 & 23.8 & 27.8 & 14.0 & 1.88 \\
\hline & Kidney medulla & 35.1 & 24.9 & 28.7 & 31.6 & 15.9 & 0.71 \\
\hline & Liver & 33.9 & 198.9 & 19.9 & 20.6 & 11.5 & 5.87 \\
\hline & Urinary bladder & 13.0 & 3.3 & 26.1 & 9.9 & $<2.0$ & 0.25 \\
\hline & Urinary bladder (contents) & 6.3 & $<2.0$ & 24.1 & 63.8 & | 1.1 & $<0.32$ \\
\hline \multirow[t]{4}{*}{ Central nervous system } & Brain (cerebrum) & 2.9 & $<2.0$ & 3.2 & 3.7 & $<2.0$ & $<0.68$ \\
\hline & Brain (cerebellum) & 2.8 & $<2.0$ & 3.7 & 5.4 & $<2.0$ & $<0.70$ \\
\hline & Brain (medulla) & $<2.0$ & $<2.0$ & 2.1 & 2.0 & $<2.0$ & NC \\
\hline & Spinal cord & 4.7 & $<2.0$ & 3.0 & 3.4 & $<2.0$ & $<0.42$ \\
\hline \multirow[t]{4}{*}{ Endocrine } & Adrenal cortex & 25.8 & 257.7 & 35.9 & 34.9 & 25.2 & 10.00 \\
\hline & Adrenal medulla & 44.3 & 136.0 & 53.4 & 51.7 & 29.2 & 3.07 \\
\hline & Pituitary gland & 24.3 & 14.1 & 26.5 & 20.6 & 12.1 & 0.58 \\
\hline & Thyroid & |5.| & 7.4 & 14.8 & 25.9 & 13.5 & 0.49 \\
\hline \multirow[t]{3}{*}{ Secretory } & Harderian gland & 3.5 & $<2.0$ & 6.4 & 9.0 & 9.4 & $<0.57$ \\
\hline & Pancreas & 8.6 & 5.1 & 6.3 & 9.7 & 7.7 & 0.59 \\
\hline & Salivary gland & 5.2 & 2.7 & 9.5 & 11.4 & 9.9 & 0.52 \\
\hline \multirow[t]{2}{*}{ Fatty } & Adipose (brown) & 25.6 & 10.4 & 32.4 & 40.6 & 19.4 & 0.41 \\
\hline & Adipose (white) & 6.2 & 2.5 & $<2.0$ & 4.7 & 2.4 & 0.40 \\
\hline Dermal & Skin (non-pigmented) & 3.4 & 2.7 & 5.2 & 7.4 & 7.4 & 0.79 \\
\hline \multirow[t]{4}{*}{ Reproductive } & Epididymis & 2.9 & $<2.0$ & 6.0 & 10.5 & 11.3 & $<0.69$ \\
\hline & Prostate gland & 4.9 & $<2.0$ & 8.0 & 7.4 & 3.9 & $<0.40$ \\
\hline & Seminal vesicles & 2.5 & $<2.0$ & 3.8 & 7.3 & $<2.0$ & $<0.81$ \\
\hline & Testis & 3.0 & 2.2 & 12.1 & 17.6 & 13.1 & 0.75 \\
\hline \multirow[t]{3}{*}{ Skeletal/muscular } & Bone & 3.9 & 5.1 & 5.6 & 3.8 & 2.5 & 1.33 \\
\hline & Heart & 30.3 & 9.8 & 35.5 & 29.4 & 20.1 & 0.32 \\
\hline & Skeletal muscle & 2.1 & $<2.0$ & 2.8 & 2.4 & $<2.0$ & $<0.95$ \\
\hline Respiratory & Lung & 75.2 & 22.9 & 65.0 & 78.2 & 33.8 & 0.31 \\
\hline \multirow[t]{8}{*}{ Alimentary canal } & Cecum & 2.7 & $<2.0$ & 6.3 & 24.6 & 8.1 & $<0.74$ \\
\hline & Cecum (contents) & $<2.0$ & $<2.0$ & $<2.0$ & 2.6 & $<2.0$ & NC \\
\hline & Large intestine & 4.6 & 2.4 & 4.6 & 13.1 & 9.9 & 0.52 \\
\hline & Large intestine (contents) & $<2.0$ & $<2.0$ & $<2.0$ & 3.2 & $<2.0$ & NC \\
\hline & Stomach (gastric mucosa) & 8.8 & 6.8 & 12.1 & 30.2 & 5.5 & 0.77 \\
\hline & Stomach (contents) & $<2.0$ & 3.4 & 8.4 & 31.7 & $<2.0$ & NC \\
\hline & Small intestine & 5.1 & $<2.0$ & 17.2 & 34.4 & 7.9 & $<0.39$ \\
\hline & Small intestine (contents) & $<2.0$ & $<2.0$ & 8.1 & 16.3 & $<2.0$ & NC \\
\hline \multirow[t]{2}{*}{ Ocular } & Eye (uvea) & 3.8 & $<2.0$ & 10.1 & 11.5 & 9.5 & $<0.52$ \\
\hline & Eye (lens) & $<2.0$ & $<2.0$ & $<2.0$ & $<2.0$ & $<2.0$ & NC \\
\hline
\end{tabular}

${ }^{\text {a }}$ This animal received a $5 \mathrm{mg} / \mathrm{kg}$ dose of CTGF at approximately $10 \mathrm{~min}$ after [ $\left.{ }^{125} \mathrm{l}\right]-\mathrm{FG}-3019$ administration

$\mathrm{NI}=$ Tissue not collected during sectioning

$\mathrm{NC}=$ Not calculable

Ratios of Rat 2/Rat I concentrations are bolded for values greater than I.0 and less than 0.33 . 

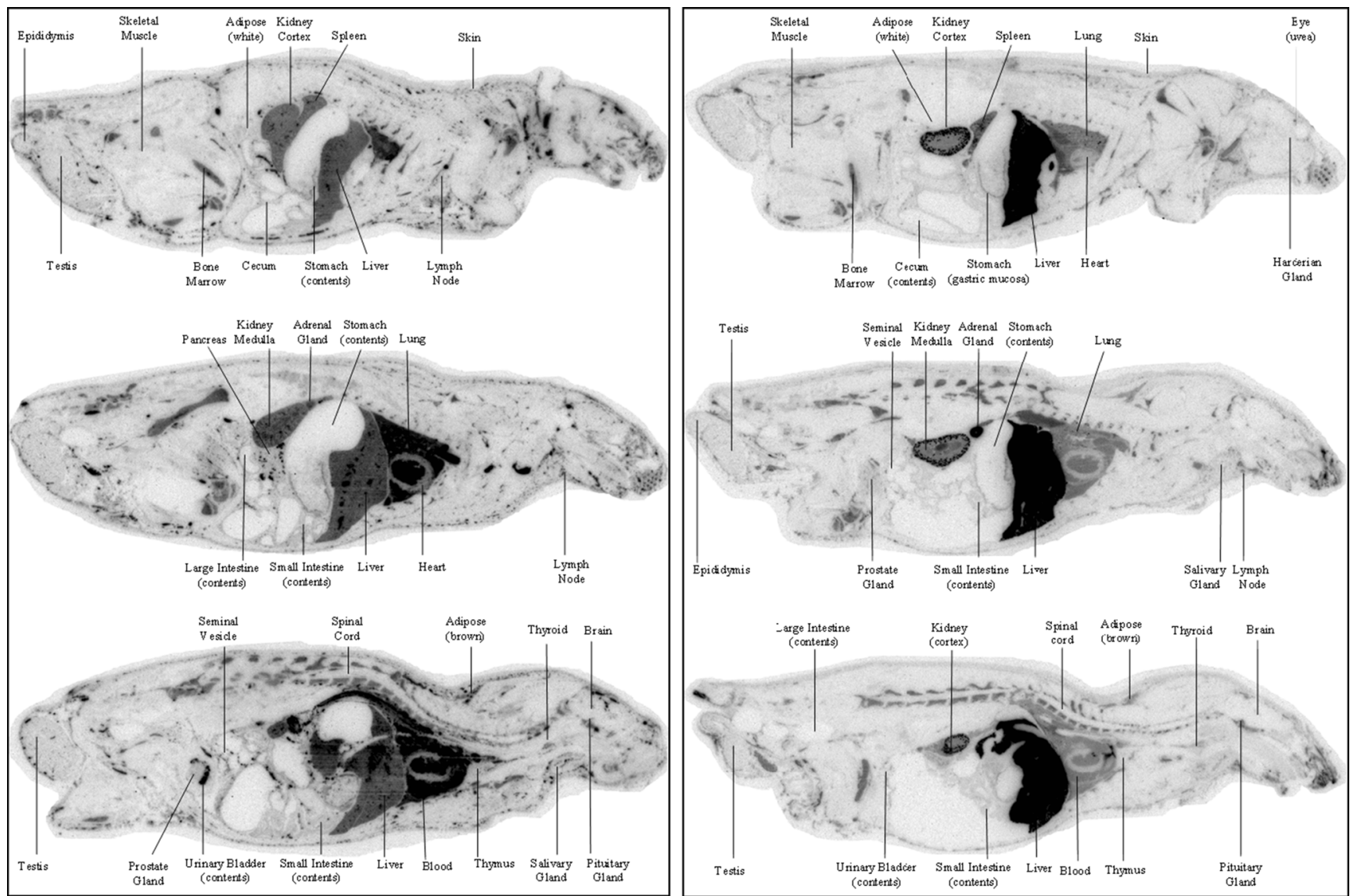

Fig. 8 Distribution of [ ${ }^{125}$ I]-FG-3019 at I 5 min after administration without or with addition of CTGF. Left panel: without administration of CTGF. Right panel: with administration of CTGF 5 min before euthanasia.

after administration to rats. Together, these data indicate that FG-3019 is subject to target-mediated elimination that contributes to its unusually short half-life and fast clearance.

Monoclonal antibodies targeting soluble antigens with low endogenous circulating concentrations relative to administered antibody (as in the case of FG-3019) generally exhibit dose-independent clearance (20). This is because the interaction of a high concentration of antibody with a low concentration of circulating antigen does not significantly affect the overall rate of antibody clearance. Dose-dependent non-linear elimination kinetics has been observed for antibodies targeting soluble ligands with relatively high endogenous concentrations such as $\operatorname{IgE}(21)$. The literature suggests that the low circulating concentrations of CTGF result from a low production rate in healthy animals, which increases with disease or after tissue injury (22-24). However, the data presented here indicate that the low plasma concentrations of CTGF normally observed are due to rapid clearance of CTGF, rather than slow production. CTGF is being continuously produced and shed into circulation at a high rate, resulting in rapid clearance of FG3019 due to target mediated elimination.

Direct measurement of the in vivo production rate of CTGF is not feasible. However, the PK data collected for both the antibody and its target, CTGF, enabled construction of a model for computation of various parameters that regulate target and antibody elimination. Although this model represents a simplification of the synthesis and distribution of CTGF and the result of introducing FG-3019 into circulation with its subsequent distribution and elimination, it predicts the PK of CTGF, CTGF-N and FG-3019 reasonably well, as demonstrated by the fit curves in Figs. 1, 2, and 3. Using this model, we can estimate that CTGF is shed into circulation at a constant rate of $0.29 \mathrm{mg} / \mathrm{kg} /$ day. In healthy rats, CTGF mRNA expression in tissues is not significantly altered at 24-h after dosing with $100 \mathrm{mg} / \mathrm{kg}$ FG-3019, suggesting that the constitutive rate of CTGF production is unaffected by FG3019 (unpublished results). It remains to be determined which tissues contribute most to this CTGF blood production rate, although cardiac atria have been reported to express high concentrations of CTGF protein (25).

Once CTGF enters the circulation, its clearance appears to be primarily through liver uptake, as demonstrated by the redistribution of $\left[{ }^{125}\right]-$-FG-3019 upon co-administration of rhCTGF. Uptake by the liver is also consistent with its rapid elimination, since approximately $100 \%$ of a rat's blood flows through the liver per minute, with about $72.5 \%$ per minute flowing through the 
Fig. 9 Immunohistochemical Localization of FG-3019. Tissue sections stained for FG-3019 are shown at I0X (upper panel) and $60 \times$ (lower panel) magnification for adrenal gland (cortex and medulla), liver, kidney (cortex) and spleen (red pulp) 5 min after IV administration of CTGF to rats dosed 10 min previously with FG-3019. Tissue sections from animals dosed with vehicle after FG-30I 9 instead of CTGF exhibited no staining for FG3019.
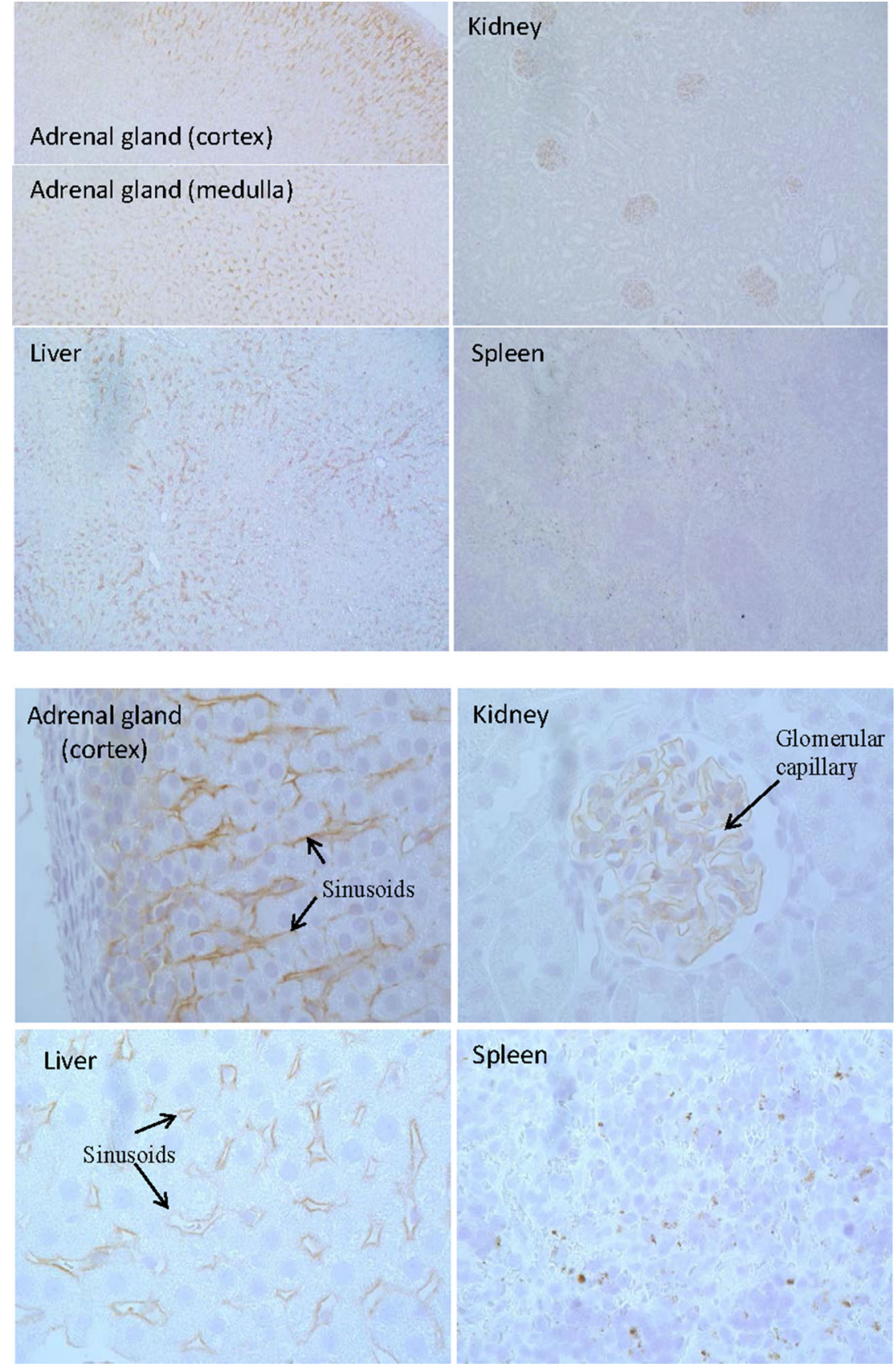

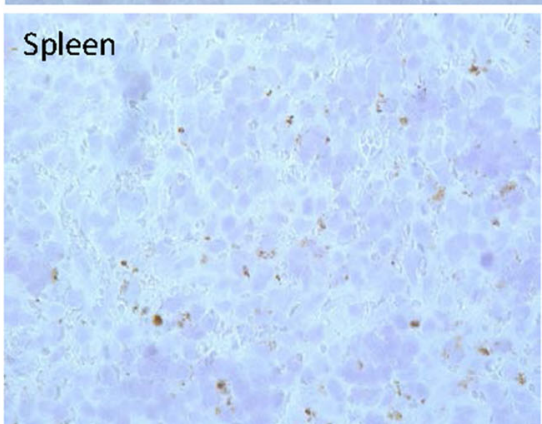

portal vein (26). Elimination of CTGF differs from that of CTGF-N, which in mice is primarily eliminated through glomerular filtration, consistent with its low molecular weight (2).

CTGF-N is produced from CTGF by proteolytic cleavage in the linker region. Because CTGF is continually being made and shed into circulation, the same is likely true for CTGF-N. The epitope to which FG-3019 binds on CTGF is in the second domain of CTGF-N. Therefore, when FG-3019 is administered and binds to CTGF-N, it increases the apparent molecular weight of CTGF-N above the renal filtration molecular weight cut-off, leading to its accumulation in circulation. The accumulation of other antibody-ligand complexes in the circulation following antibody administration has been modeled successfully (27). For example hepcidin, a small peptide hormone which is normally excreted by renal filtration, accumulates in the circulation in an antibody complex (10). The observation of increased circulating concentrations of CTGF-N upon FG-3019 administration, coupled with the fact that co-administration of rhCTGF-N had no impact on the clearance of FG-3019, while whole CTGF significantly enhanced it, indicates that the motif that mediates liver uptake of CTGF resides in its C-half.

Several cell surface molecules have been reported to interact with CTGF domains 3 or 4 (28). Among them, one of the most likely candidate receptors mediating uptake of CTGF into liver is LRP1. LRP1 is a scavenger receptor that has been reported to 
bind many ligands (29) including CTGF (30) . In the liver, LRP1 is expressed in both hepatocytes and Kupffer cells (resident macrophages) and it functions to clear plasma protein ligands (29). LRP1 in macrophages also suppresses vascular remodeling by modulating response to TGF $\beta$ (31), which may occur at least partially though uptake of CTGF (31). In chondrocytes, LRP1 is thought to mediate CTGF transcytosis (32). There are also two closely related members of the LRP1 family that are expressed in the adrenal gland, LRP1b (33) and kidney, LRP2/megalin $(34,35)$. LRP2 has been shown to bind CTGF in the kidney, and mediate its excretion (2). Thus, the localization of these three related scavenger receptors could account for the majority of the rapid clearance of $\left[{ }^{125} \mathrm{~T}\right]-\mathrm{FG}-3019$ upon co-administration of rhCTGF in the QWBA experiment.

The cell surface expression of LRP1, LRP1b and LRP2 is aided by the endoplasmic reticulum (ER) chaperone RAP (receptor-associated protein, LRPAP1), which binds tightly to these receptors at neutral $\mathrm{pH}$ preventing premature ligand binding during folding and transport to the cell surface $(29,36)$. RAP is localized to the ER by a 4 amino acid sequence at its C-terminus, but is secreted in a soluble form when these amino acids are omitted (37). When injected into animals, RAP is rapidly cleared from the circulation via uptake by the liver and kidney (7). Despite its rapid clearance, administration of the soluble form of RAP inhibits plasma clearance of tissue type plasminogen activator and tissue factor pathway inhibitor in rats, presumably by interfering with binding of these factors to LRP1 and related proteins $(7,38)$. Similarly, co-administration of RAP with FG-3019 and rhCTGF resulted in a measurable slowing of the clearance of FG-3019. This observation suggests that at least part of the clearance of CTGF (and CTGF/FG3019 complexes) from circulation is via binding to one or more of these scavenger receptors. Additional experiments will be necessary to assess the extent of CTGF clearance that is mediated by LRP1 and related scavenger receptors.

Pharmacokinetic modeling of target-mediated drug disposition (TMDD) predicts that the true terminal rate of elimination is independent of the dose of drug administered (13). This can be seen in the parallelism of the terminal FG-3019 disappearance rates in the curves obtained from the kinetic model shown in Fig. 1. However, as can also be seen in Fig. 1, sample collection from animals administered high doses of FG-3019 was terminated too soon to establish the true terminal elimination rates. This failure to collect samples at sufficiently late time points explains the apparent dose-dependence of the experimentally determined half-lives. Another interesting observation from computer modeling is that the affinity of FG-3019 for CTGF appears to be at least 120-fold weaker in viwo than predicted by the affinity determined in vitro (by radioimmunoassay). This suggests that blood flow or components in blood may weaken the antibodyligand interaction. As shown in Fig. 4 and previously mentioned, co-administration of rhCTGF rapidly eliminated circulating FG-3019 in proportion to the amount of CTGF administered.
When dosed at a 2:1 molar ratio to FG-3019, CTGF caused more than $90 \%$ of the FG-3019 in plasma to disappear from circulation in less than $3 \mathrm{~min}$. To our knowledge, the magnitude of rhCTGF's effect on FG-3019 pharmacokinetics is unprecedented for target-mediated antibody elimination by a soluble ligand. Similar behavior has been described for the effect of avidin on synthetically biotinylated $\operatorname{IgG}$, but this is a special case that is not dependent on ligand recognition through the complementarity determining regions of the antibody (39).

The ability of co-administered CTGF to trigger rapid antibody elimination was also observed for two other antiCTGF monoclonal antibodies that have different binding epitopes on CTGF from the one recognized by FG-3019 (data not shown). This suggests that any anti-CTGF antibody (or any molecule that binds to CTGF) may be subject to targetmediated elimination. Consequently, any tightly associated complex between CTGF and an endogenous binding partner might also be cleared rapidly once the complex dissociates from the extracellular matrix and enters the circulation.

In conclusion, the unusually rapid clearance and short halflife of FG-3019 results at least in part from target-mediated elimination. The data suggest that CTGF is constitutively produced and shed into circulation at a higher rate than has previously been appreciated. Once in circulation, CTGF appears to be removed upon passage through the liver, and in the process facilitates clearance of anything that is bound to it. It remains to be determined if this mechanism has a physiologic role in the homeostasis of any of the putative CTGF binding partners. However, it clearly has relevance for the administration of any inhibitor of CTGF, which will likely be rapidly cleared and therefore will need to be administered at higher doses and/or more frequently than would be necessary if it were not subject to target-mediated elimination.

\section{ACKNOWLEDGMENTS AND DISCLOSURES}

We acknowledge Dr. William (Bill) Usinger, an early leader in the development of FG-3019, Dr. Leon Xu and Julia Gray, who generated reagents and contributed to the original observations of the unusually rapid clearance and short half-life of FG-3019, Chadwick Strange for technical assistance with dose formulations, and Dr. Roel Goldschmeding for helpful discussions.

All authors with the exception of W.K. are employees of FibroGen, Inc.

Open Access This article is distributed under the terms of the Creative Commons Attribution 4.0 International License (http://creativecommons.org/licenses/by/4.0/), which permits unrestricted use, distribution, and reproduction in any medium, provided you give appropriate credit to the original author(s) and the source, provide a link to the Creative Commons license, and indicate if changes were made. 


\section{REFERENCES}

1. Holbourn KP, Acharya KR, Perbal B. The CGN family of proteins: structure-function relationships. Trends Biochem Sci. 2008;33(10):461-73.

2. Gerritsen KG, Peters HP, Nguyen TQ, Koeners MP, Wetzels JF, Joles JA, et al. Renal proximal tubular dysfunction is a major determinant of urinary connective tissue growth factor excretion. Am J Physiol Renal Physiol. 2010;298(6):F1457-64.

3. Dendooven A, Gerritsen KG, Nguyen TQ, Kok RJ, Goldschmeding R. Connective tissue growth factor (CTGF/CGN2) ELISA: a novel tool for monitoring fibrosis. Biomarkers. 2011;16(4):289-301.

4. Riser BL, Barnes JL, Varani J. Balanced regulation of the CGN family of matricellular proteins: a novel approach to the prevention and treatment of fibrosis and cancer. J Cell Commun Signal. 2015;9(4):327-39.

5. ClinicalTrials.gov clinicaltrials.gov, internet communication Sep 30, 2010.

6. Wang QJ, Frazier K, Nichols B, Zhang W, Fourney P, Folz A, et al. Effects of a monoclonal antibody to connective tissue growth factor (CTGF) in experimental organ fibrosis. Am Soc Nephrol. 2002;13: 315A.

7. Warshawsky I, Bu G, Schwartz AL. 39-kD protein inhibits tissuetype plasminogen activator clearance in vivo. J Clin Invest. 1993;92(2):937-44.

8. D'Argenio DZ, Schumitzky A, Wang X. ADAPT 5 User's guide: pharmacokinetic/pharmacodynamic systems analysis software. Biomed Simul Resource 2009.

9. Tang C, Prueksaritanont T. Theoretical analysis of interplay of therapeutic protein drug and circulating soluble target: temporal profiles of 'free' and 'total' drug and target. Pharm Res. 2011;28(10):2447-57.

10. Xiao JJ, Krzyzanski W, Wang YM, Li H, Rose MJ, Ma M, et al. Pharmacokinetics of anti-hepcidin monoclonal antibody $\mathrm{Ab}$ $12 \mathrm{~B} 9 \mathrm{~m}$ and hepcidin in cynomolgus monkeys. AAPS J. 2010;12(4):646-57.

11. Iadonato SP, Bu G, Maksymovitch EA, Schwartz AL. Interaction of a $39 \mathrm{kDa}$ protein with the low-density-lipoprotein-receptorrelated protein (LRP) on rat hepatoma cells. Biochem J. 1993;296(Pt 3):867-75.

12. Mager DE, Krzyzanski W. Quasi-equilibrium pharmacokinetic model for drugs exhibiting target-mediated drug disposition. Pharm Res. 2005;22(10):1589-96.

13. Mager DE, Jusko WJ. General pharmacokinetic model for drugs exhibiting target-mediated drug disposition. J Pharmacokinet Pharmacodyn. 2001;28(6):507-32.

14. Peletier LA, Gabrielsson J. Dynamics of target-mediated drug disposition: characteristic profiles and parameter identification. J Pharmacokinet Pharmacodyn. 2012;39(5):429-51.

15. Yan X, Mager DE, Krzyzanski W. Selection between MichaelisMenten and target-mediated drug disposition pharmacokinetic models. J Pharmacokinet Pharmacodyn. 2010;37(1):25-47.

16. Gillen CM, Takamata A, Mack GW, Nadel ER. Measurement of plasma volume in rats with use of fluorescent-labeled albumin molecules. J Appl Physiol (1985). 1994;76(1):485-9.

17. Bazin-Redureau MI, Renard CB, Scherrmann JM. Pharmacokinetics of heterologous and homologous immunoglobulin $\mathrm{G}, \mathrm{F}\left(\mathrm{ab}^{\prime}\right) 2$ and $\mathrm{Fab}$ after intravenous administration in the rat. J Pharm Pharmacol. 1997;49(3):277-81.

18. Singh AP, Krzyzanski W, Martin SW, Weber G, Betts A, Ahmad A, et al. Quantitative prediction of human pharmacokinetics for mAbs exhibiting target-mediated disposition. AAPS J. 2015;17(2): 389-99.
19. Adler SG, Schwartz S, Williams ME, Arauz-Pacheco C, Bolton WK, Lee T, et al. Phase 1 study of anti-CTGF monoclonal antibody in patients with diabetes and microalbuminuria. Clin J Am Soc Nephrol. 2010;5(8):1420-8.

20. Dostalek M, Gardner I, Gurbaxani BM, Rose RH, Chetty M. Pharmacokinetics, pharmacodynamics and physiologically-based pharmacokinetic modelling of monoclonal antibodies. Clin Pharmacokinet. 2013;52(2):83-124.

21. Mould DR, Sweeney KR. The pharmacokinetics and pharmacodynamics of monoclonal antibodies-mechanistic modeling applied to drug development. Curr Opin Drug Discov Devel. 2007;10(1):84-96.

22. Ito Y, Aten J, Bende RJ, Oemar BS, Rabelink TJ, WeeningJJ, et al. Expression of connective tissue growth factor in human renal fibrosis. Kidney Int. 1998;53(4):853-61.

23. Igarashi A, Nashiro K, Kikuchi K, Sato S, Ihn H, Grotendorst G, et al. Significant correlation between connective tissue growth factor gene expression and skin sclerosis in tissue sections from patients with systemic sclerosis. J Invest Dermatol. 1995;105(2):280-4.

24. di Mola FF, Friess H, Martignoni ME, Di Sebastiano P, Zimmermann A, Innocenti P, et al. Connective tissue growth factor is a regulator for fibrosis in human chronic pancreatitis. Ann Surg. 1999;230(1):63-71.

25. de Chuva Sousa Lopes SM, Feijen A, Korving J, Korchynskyi O, Larsson J, Karlsson S, et al. Connective tissue growth factor expression and Smad signaling during mouse heart development and myocardial infarction. Dev Dyn. 2004;231(3):542-50.

26. Davies B, Morris T. Physiological parameters in laboratory animals and humans. Pharm Res. 1993;10(7):1093-5.

27. Davda JP, Hansen RJ. Properties of a general PK/PD model of antibody-ligand interactions for therapeutic antibodies that bind to soluble endogenous targets. MAbs. 2010;2(5): 576-88

28. Chen CC, Lau LF. Functions and mechanisms of action of CGN matricellular proteins. Int $\mathrm{J}$ Biochem Gell Biol. 2009;41(4):771-83.

29. Lillis AP, Van Duyn LB, Murphy-UllrichJE, Strickland DK. LDL receptor-related protein 1: unique tissue-specific functions revealed by selective gene knockout studies. Physiol Rev. 2008;88(3):887918.

30. Segarini PR, Nesbitt JE, Li D, Hays LG, Yates IIIJR, Carmichael DF. The low density lipoprotein receptor-related protein/alpha2macroglobulin receptor is a receptor for connective tissue growth factor. J Biol Chem. 2001;276(44):40659-67.

31. Muratoglu SC, Belgrave S, Hampton B, Migliorini M, Coksaygan $\mathrm{T}$, Chen $\mathrm{L}$, et al. LRPl protects the vasculature by regulating levels of connective tissue growth factor and $\mathrm{HtrAl}$. Arterioscler Thromb Vasc Biol. 2013;33(9):2137-46.

32. Kawata K, Kubota S, Eguchi T, Aoyama E, Moritani NH, Kondo $\mathrm{S}$, et al. Role of LRP1 in transport of CGN2 protein in chondrocytes. J Cell Sci. 2012;125(Pt 12):2965-72.

33. Marschang P, Brich J, Weeber EJ, Sweatt JD, Shelton JM, Richardson JA, et al. Normal development and fertility of knockout mice lacking the tumor suppressor gene LRP1b suggest functional compensation by LRP1. Mol Cell Biol. 2004;24(9):3782-93.

34. Kerjaschki D, Farquhar MG. Immunocytochemical localization of the Heymann nephritis antigen (GP330) in glomerular epithelial cells of normal Lewis rats. J Exp Med. 1983;157(2):667-86.

35. Marzolo MP, Farfan P. New insights into the roles of megalin/ LRP2 and the regulation of its functional expression. Biol Res. 2011;44(1):89-105.

36. Willnow TE, Armstrong SA, Hammer RE, Herz J. Functional expression of low density lipoprotein receptor-related protein is controlled by receptor-associated protein in vivo. Proc Natl Acad Sci U S A. 1995;92(10):4537-41. 
37. Bu G, Geuze HJ, Strous GJ, Schwartz AL. 39 kDa receptorassociated protein is an ER resident protein and molecular chaperone for LDL receptor-related protein. EMBO J. 1995;14(10): 2269-80.

38. Narita M, Bu G, Herz J, Schwartz AL. Two receptor systems are involved in the plasma clearance of tissue-type plasminogen activator (t-PA) in vivo. J Clin Invest. 1995;96(2):1164-8.

39. Sinitsyn VV, Mamontova AG, Checkneva YY, Shnyra AA, Domogatsky SP. Rapid blood clearance of biotinylated IgG after infusion of avidin. J Nucl Med. 1989;30(1): 66-9. 